University of Nebraska - Lincoln DigitalCommons@University of Nebraska - Lincoln

2012

\title{
Research Perspectives on the Public and Fire Management: A Synthesis of Current Social Science on Eight Essential Questions
}

Sarah M. McCaffrey

U.S. Forest Service

Christine S. Olsen

Oregon State University

Follow this and additional works at: http://digitalcommons.unl.edu/jfspsynthesis

Part of the Forest Management Commons, Other Forestry and Forest Sciences Commons, and the Wood Science and Pulp, Paper Technology Commons

McCaffrey, Sarah M. and Olsen, Christine S., "Research Perspectives on the Public and Fire Management: A Synthesis of Current Social Science on Eight Essential Questions" (2012). JFSP Synthesis Reports. 17.

http://digitalcommons.unl.edu/jfspsynthesis/17

This Article is brought to you for free and open access by the U.S. Joint Fire Science Program at DigitalCommons@University of Nebraska - Lincoln. It has been accepted for inclusion in JFSP Synthesis Reports by an authorized administrator of DigitalCommons@University of Nebraska - Lincoln. 
USDA

United States

Department of

Agriculture

Forest

Service

Northern

Research Station

General Technical

Report NRS-104
Research Perspectives on the Public and Fire Management: A Synthesis of Current Social Science on Eight Essential Questions

Sarah M. McCaffrey and Christine S. Olsen
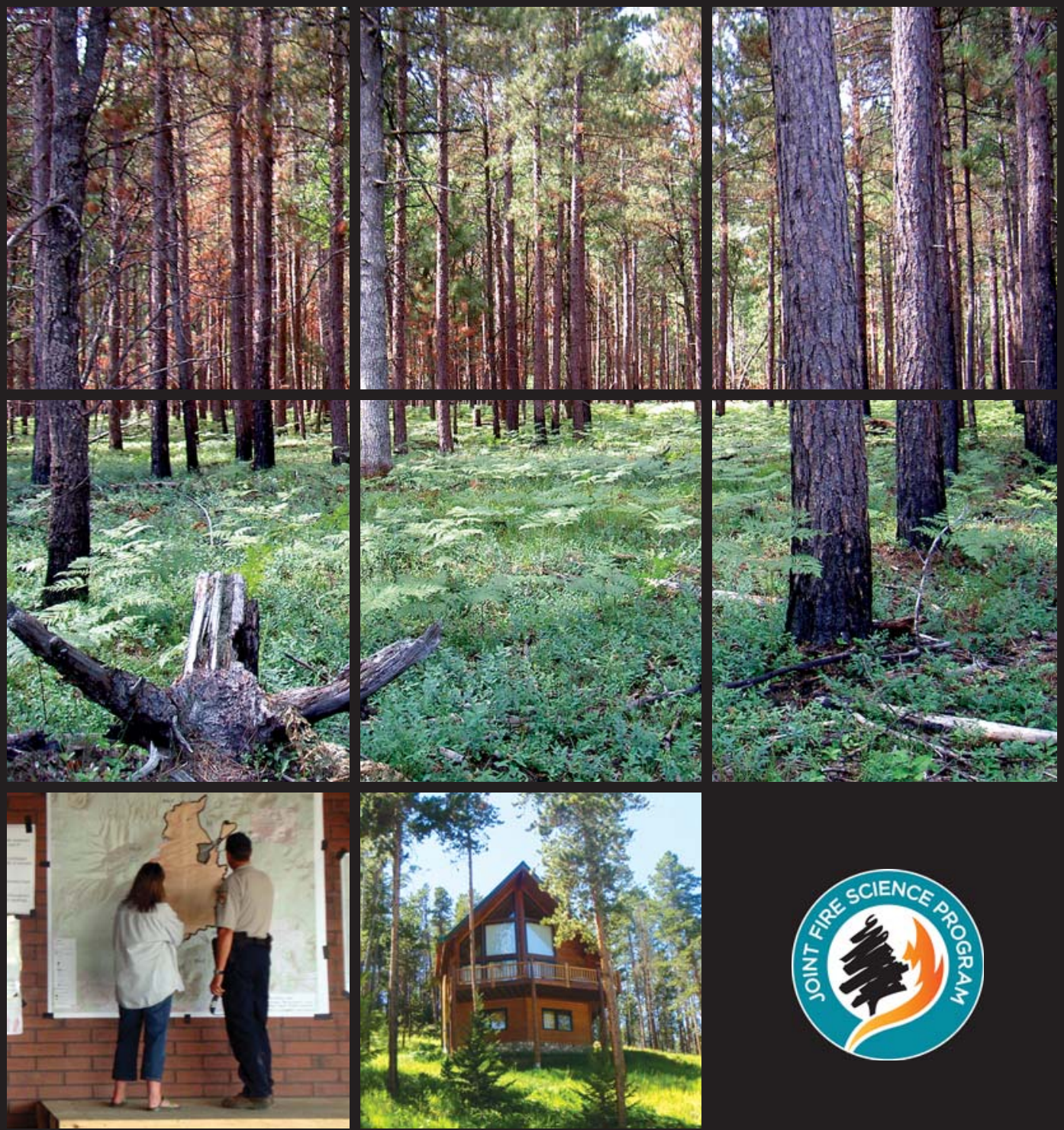


\begin{abstract}
As part of a Joint Fire Science Program project, a team of social scientists reviewed existing fire social science literature to develop a targeted synthesis of scientific knowledge on the following questions: 1 . What is the public's understanding of fire's role in the ecosystem? 2. Who are trusted sources of information about fire? 3 . What are the public's views of fuels reduction methods, and how do those views vary depending on citizens' location in the wildland-urban interface or elsewhere? 4. What is the public's understanding of smoke effects on human health, and what shapes the public's tolerance for smoke? 5. What are homeowners' views of their responsibilities for home and property protection and mitigation, e.g., defensible space measures? 6. What role does human health and safety play in the public's perceptions of fire and fire management? 7 . What are the public's views on the role and importance of costs in wildfire incident response decisions? 8. To the extent that information is available, how do findings differ among ethnic and cultural groups, and across regions of the country?

Despite limited fire research specific to the questions on costs, and human health and safety, common findings on all these interrelated topics are summarized in this document. Research has found that the public has a fairly sophisticated understanding of fire's ecological role and the environmental factors that can increase fire risk. The public obtains information on fire from a wide variety of sources, but findings consistently show that interactive information sources are both generally preferred and more effective than unidirectional sources. As a way to improve ecosystem health and reduce fire risk, active land management generally has greater citizen support than a no-action alternative. Most respondents accept the practice of prescribed fire for active forest management and tolerate the accompanying smoke; in contrast, smoke is a highly salient issue for households with health concerns. The public tends to see mitigating the fire risk as a shared responsibility with landowners, whether public or private, responsible for taking appropriate action on their own property. Cost figures in to citizens' decisionmaking about actions to protect property before a wildfire but may be less of a priority during incident response. Except for ethnicity or race, little evidence was found of meaningful variation in public response to fire management based on socio-demographic characteristics or geographic variation.
\end{abstract}

\title{
Authors
}

SARAH M. McCAFFREY is a research forester with the U.S. Forest Service, Northern Research Station, Evanston, IL.

CHRISTINE S. OLSEN is a research associate at Oregon State University, College of Forestry, Department of Forest Ecosystems and Society, Corvallis, OR.

\section{Cover Photos}

Photos by Sarah McCaffrey, U.S. Forest Service.

Manuscript received for publication February 2012

\begin{tabular}{ll}
\hline \hline Published by: & \\
USDA FOREST SERVICE & For additional copies: \\
11 CAMPUS BLVD., SUITE 200 & USDA Forest Service \\
NEWTOWN SQUARE, PA 19073-3294 & Publications Distribution \\
& 359 Main Road \\
September 2012 & Delaware, OH 43015-8640 \\
\hline \hline
\end{tabular}




\section{INTRODUCTION}

In August 2009, the executive team of Partners in Fire Education (PIFE) asked the Joint Fire Science Program for assistance with identifying how research could best inform its public outreach efforts to increase public understanding of fire's natural role in ecosystems and the benefits of fire management to ecosystems and public health and safety. To take advantage of the substantial base of potentially relevant research already available, the Joint Fire Science Program funded a targeted synthesis of scientific knowledge on public views and understanding of fire and management. Specifically, the synthesis was targeted on the following questions:

1. What is the public's understanding of fire's role in the ecosystem?

2. Who are trusted sources of information about fire?

3. What are the public's views of fuels reduction methods, and how do those views vary depending on citizens' location in the wildlandurban interface (WUI) or elsewhere?

4. What is the public's understanding of smoke effects on human health, and what shapes the public's tolerance for smoke?

5. What are homeowners' views of their responsibilities for home and property protection and mitigation, e.g., defensible space measures?

6. What role does human health and safety play in the public's perceptions of fire and fire management?

7. What are the public's views on the role and importance of costs in wildfire incident response decisions?

8. To the extent that information is available, how do findings differ among ethnic and cultural groups, and across regions of the country?

This document addresses these questions through a summary of common findings and patterns identified from existing fire research.

\section{METHODS}

The process began by reviewing the questions of interest and making a list of relevant keywords that could be used in database searches, as well as a list of authors known to have contributed on each topic. Keywords included a wide range of words and phrases, such as prescribed fire, smoke, suppression, health, ethnic, communication, mitigation, and knowledge. Database searches were then conducted to collect as much literature as possible on the questions of interest using keyword and author searches in the following databases: Agricola, Academic Search Premier, CAB Abstracts, GreenFILE, Treesearch (U.S. Forest Service), and Web of Science. Additionally, commonly cited journals (e.g., Journal of Forestry, International Journal of Wildland Fire, Society and Natural Resources, and Environmental Management) were individually searched for relevant literature. To best represent current public views and understanding, the search was limited to publications since 2000. Sources included journal articles, technical reports, proceedings, project reports, working papers, book chapters, and shorter articles such as science briefs. Although most sources were peer reviewed, a few were not (i.e., project reports, science briefs), and these are indicated with a * in the Literature Cited section.

A team of social scientists conducted the literature search in spring 2010. Two additional searches were conducted in May and July 2011 to ensure new articles were included. Searches were periodically cross-checked to ensure we were capturing as much relevant literature as possible. Finally, to further ensure adequate coverage, the reference lists for approximately 10 percent of the articles that most directly addressed the questions of interest were searched so that no articles were missed. A database was then created in Excel to organize key points related to PIFE's questions of interest. Each of the 
eight questions was further divided into subtopics. This spreadsheet was used as a guide to synthesize relevant findings for each question.

Studies have been conducted throughout the United States, and a few international locations, using a variety of methods. Although both methods and research locations are on occasion referenced in the following discussion, specific methods and study locations for each article are summarized in Appendix 1. Where multiple papers have been published from a single study, they have been listed in the Appendix under the most commonly cited author of that study. When a specific study result is reported in multiple papers, we cite only one paper in the text to avoid inflating findings.

The main methods used in the studies are interviews, focus groups, and surveys. Each method has advantages in the type of information it can provide. Qualitative methods, such as focus groups and interviews, provide a more in-depth understanding of how people think about different fire issues, including the range of factors and interactions that shape decisions, and can provide insight into the role of different contextual factors. Surveys provide a clearer picture of the proportion of the sampled population that holds a certain belief or supports an activity. They also allow researchers to better identify significant relationships and compare findings between study sites. For each question we worked to identify patterns in findings across both qualitative and quantitative studies. While the findings from non-probability samples used in most qualitative research are not generalizable to a broader population, identifying a pattern that holds across multiple studies using different methods provides a fairly robust identification of important social dynamics.

\section{FINDINGS}

Most of the studies reviewed here involved members of the public who live or recreate near or in fire-prone wildland-urban interface (WUI) areas, often adjacent to a National Forest. Many researchers target WUI residents because they are initially the most relevant audience for mitigation programs. Thus the "public" described here may not represent the general public. However, it is worth noting that those studies that used a national sample or sampled areas with little wildfire risk found results substantially similar to those that sampled individuals in high fire risk areas (see Differences discussion). Unless noted otherwise, when we refer to the "public" throughout this document, we are referring to residents of and recreation visitors to the WUI.

In the following "answers" to each question, we have attempted to identify key patterns in existing research and provide specific results from individual studies to demonstrate the range of findings. We found varied levels of research relevant to each question. The only question that was the focus of multiple studies was the question about public views of fuels reduction methods. For the remaining questions, relevant data tended to be found, at varying levels of detail, in studies primarily focused on assessing public response to fuels reduction or defensible space methods. Because most of this work focused on prefire mitigation issues, we found little relevant research regarding incident response. The limited number of studies on some topic areas made it difficult to identify clear patterns for certain questions. Therefore, when we had only limited data specific to a question, we looked at a broader interpretation of the question. It is also worth noting that results show that many of the topics are interlinked in the public's mind. As such, some of the best answers to one question may be found in several places throughout this document. 


\section{KNOWLEDGE}

\section{What is the public's understanding of fire's role in the ecosystem?}

The public's understanding of fire's role in the ecosystem is addressed in both qualitative and quantitative studies. Overall, the research paints a picture of a public that often has a sophisticated understanding of how fire fits into the ecosystemin terms of its ecological role as well as the environmental characteristics that contribute to increased fire risk. In qualitative studies, understanding of fire's role in the environment is referenced primarily in two ways: 1) awareness of the risks of living in a natural landscape and perceptions that the current forest is unhealthy from too many trees and/or a buildup of fuel (Brenkert-Smith 2011, Burns and Cheng 2007, Carroll et al. 2005, Cohn et al. 2008, Kent et al. 2003, McCaffrey 2008b, Paveglio et al. 2011, Weisshaupt et al. 2007) and 2) discussions of overall forest management and the need to reintroduce fire, whether via prescribed fire or allowing some naturally ignited fires to burn (Knotek et al. 2008, McFarlane et al. 2007, Mendez et al. 2003, Winter and Cvetkovich 2008).

Many studies using interviews or focus groups found that participants' comments indicated a good or even a sophisticated understanding of the factors that contribute to fire risk, and of fire behavior and ecology (Brenkert-Smith 2011, Flint 2006, Gordon et al. 2010, McCaffrey 2008b, Monroe et al. 2006, Paveglio et al. 2011, Vining and Merrick 2008). For example, Monroe et al. (2006) found that the majority ( 84 percent) of respondents were aware of the fire risk and had a reasonable understanding of environmental conditions that influenced this risk, including fire behavior and ecological conditions. Similarly, Paveglio et al. (2011) found that fire was seen as the main natural risk in the Spokane, WA, area and that participants had detailed knowledge about fire, including both its risks and its beneficial ecological role. In Minnesota, Vining and Merrick (2008) found that participants understood the complex nature and tradeoffs of different fire management practices and understood "that firemanagement techniques have just as many (or perhaps more) ecological benefits as negative ecological consequences." Even respondents in West Virginia, which is not generally seen as a high fire hazard state, were found to have a nuanced understanding of fire, including its consequences and likelihood of occurrence given local vegetation, climate, and topography (Gordon et al. 2010).

A number of surveys asking specific questions to measure knowledge levels provide additional evidence that the majority of individuals have a reasonable understanding of fire ecology. Respondents on Long Island, NY, showed overall awareness of local fire history and general forest characteristics (Ryan and Wamsley 2008). In four western states, Brunson and Shindler (2004) found respondents were reasonably knowledgeable about fire; at least 79 percent recognized that some plants need fire to regenerate and at least half recognized that fires do not typically kill most animals and that fires can impact stream water quality. However, a larger proportion (4977 percent) thought that fires kill most large trees, which was not an accurate reflection of the local fire regime, except in Utah. In another survey, participants exhibited similarly high knowledge levels: more than 90 percent recognized that fire had played a significant role in shaping forests in the western United States and more than three-quarters recognized that wildfire suppression had increased fire risk (Toman and Shindler 2006). In Arizona, Collins (2009) found that four-fifths of households answered all seven questions related to local fire ecology correctly. Finally, Jacobson et al. (2001) found that at least two-thirds of respondents accurately answered five questions about fire in Florida, including its role in forest renewal (79 percent) and in creating wildlife habitat (67 percent). 


\section{Education}

Studies also suggest that even modest educational efforts can significantly raise both the public's knowledge of and its support for different fire management practices. Toman and Shindler (2006) found that for those with lower levels of knowledge of and support for fire management, exposure to educational materials resulted in significant increases in both understanding and support. Similarly, participatory workshops in Idaho significantly increased both participants' fire knowledge and supportive attitudes toward fire management (Parkinson et al. 2003). In Florida, Loomis et al. (2001) found that the proportion of respondents who agreed with use of periodic underburning (64 percent) increased markedly (to 87 percent) after respondents received basic educational information.

\section{Summary}

Overall, studies provide ample evidence that members of the public recognize fire's ecological role. Indeed, findings demonstrate that, particularly for those in high fire hazard areas, individuals often have a fairly sophisticated understanding of fire's ecological role. When knowledge levels are lower, a smaller number of studies suggest that provision of appropriate information can effectively increase knowledge levels and treatment support. The apparent efficacy of outreach efforts raises the question of how people learn about fire, a topic addressed in the next section. 


\section{TRUSTED SOURCES OF INFORMATION}

Who are trusted sources

of information about fire?

Answering this question is not as straightforward as it might appear because trust, whether it is attached to an individual or an organization, is dynamic and is highly dependent upon actions and relationships. Given this complexity, a full assessment of factors that influence trust is beyond the scope of this project; however, the topic is currently being assessed in another JFSP project (\#10-3-01-25). We have therefore interpreted the question to mean, "Which information sources do people tend to use to learn about fire management and which sources do they find most trustworthy and useful?" As only one study (Taylor et al. 2007) focused on information needs during a fire, the focus of discussion is on pre-fire information.

\section{Information Sources}

At a general level, government is the preferred source of information on fire issues (Jarrett et al. 2009, McCaffrey et al. 2011, McGee 2011, Monroe and Nelson 2004, Ostergren et al. 2006, Weisshaupt et al. 2007). This preference is consistent with perceptions that public education about fire risk and mitigation is in part the government's responsibility (see Responsibility discussion). People also prefer information that takes local context into account and that comes from local sources (Kent et al. 2003, McCaffrey 2004, Ostergren et al. 2006, Parkinson et al. 2003, Taylor et al. 2007, Vogt et al. 2009). For instance, Vogt et al. (2009) found a preference for local information sources; materials from the local fire department or other local government agencies, and presentations to homeowners, met with the most positive response among those studied.

Findings show that there is no single best information source: individuals generally obtain information on fire risk from multiple sources, and the use of sources varies by location. This variability is best demonstrated by the variability in specific study findings. In five southern states, state forestry agencies ( 38 percent) were the most frequently cited information source on wildfire prevention, followed by friends and family ( 25 percent) and state or county extension offices (24 percent) (Jarrett et al. 2009). In another study, McCaffrey et al. (2011) found that when asked about sources of information on fire risk, respondents most frequently mentioned personal experience, followed by common sense, neighbors or a homeowners' association, and agency outreach. But the researchers also found that the use of each source varied across the five study sites (e.g., 26 percent used agency outreach in one site and 56 percent did in another). Another example comes from the San Bernardino Mountains in California, where the top five preferred fire information sources were Forest Service public meetings (provided they allowed for dialogue), community meetings, websites, brochures, and articles in the local paper (Winter and Cvetkovich 2010).

\section{Source Trustworthiness}

Which sources are seen as more credible or trustworthy varies by site, although government sources tend to rank highest. Shindler et al. (2009) found that the most trustworthy sources were often public agency sources; more than 75 percent of people surveyed considered public agency sources, except public meetings, trustworthy. Most of the information sources Toman et al. (2006) studied were seen as trustworthy, with more than 90 percent of the respondents finding all but 3 out of 11 sources trustworthy; Internet web pages, conversations with agency employees, and government public meetings were the exceptions. The most trustworthy sources were Smokey Bear, interpretive centers, and guided field trips (Toman et al. 2006). Near Colorado Springs, $\mathrm{CO}$, residents were asked to rate different wildfire information sources based on their experience with the source (Kent et al. 2003). The National Park Service 
was seen as the most credible information source, followed by county/city fire departments, neighbors/ friends, the Colorado State Forest Service, and the U.S. Forest Service (Kent et al. 2003). The National Park Service's high credibility is notable because the Forest Service owns a substantial amount of land in the area, yet the closest National Park is more than 100 miles away.

Although government sources are generally seen as trustworthy, government communication efforts are given more varied assessments. Paveglio et al. (2009) found that participants in focus groups in Spokane were generally dissatisfied with the U.S. Forest Service's communication efforts and showed a general lack of familiarity and trust in the agency as an organization. In Missouri, respondents only slightly agreed that the government did a good job of communicating about forest issues (Vogt et al. 2007). Shindler et al. (2011) found that the majority of respondents from the Great Basin in the western United States gave low ratings to government outreach efforts. A similar study in the Midwest found slightly more positive views; roughly equal proportions either agreed, disagreed, had a neutral opinion, or had no opinion about whether the Forest Service was doing a good job of providing information about its management activities, being open to public input in management decisions, and building trust and cooperation with citizens (Shindler et al. 2009). By contrast, Absher and Vaske (2011) found at least 82 percent agreeing that in relation to forest fire issues the U.S. Forest Service provided the best available information, enough information for respondents to decide what actions they needed to take, truthful information about related safety issues, and timely information.

\section{Source Usefulness}

Perceptions of the usefulness of information sources also vary widely. In Oregon and Washington, newspapers and magazines had the largest percentage indicate they were moderately to highly useful, followed by friends/relatives, timber groups, and the U.S. Forest Service, while environmental groups and the Internet had the lowest ranking (Shindler and Toman 2003). This study reported findings from a follow-up survey after 4 years and found that usefulness of only two information sources changed significantly: the Forest Service as a useful information source decreased (from 60 to 47 percent of respondents) and timber groups as a useful source increased (from 39 to 50 percent).

In a Colorado study, the county and city fire departments were seen as the most helpful information source, followed (in order) by the Colorado State Forest Service, Firewise community information, media reports, and the U.S. Forest Service (Kent et al. 2003). In three Midwest states, Shindler et al. (2009) asked about helpfulness of a variety of general (e.g., TV, family and friends) and public agency information sources (e.g., brochures, elementary school programs). In general, one-third of respondents found each information source very helpful and half found them slightly helpful. However, two sources, conversations with agency personnel and guided field trips, were clearly seen as more helpful, with at least half of the survey participants finding each very helpful and only 11 percent finding them not at all helpful. Two sources, environmental groups and the Internet, were seen as less helpful, with larger proportions finding them slightly (42 percent and 44 percent, respectively) or not at all (45 percent and 35 percent, respectively) helpful. In four western states, Toman et al. (2006) examined differences in helpfulness and trustworthiness of unidirectional (e.g., TV public service messages, brochures) versus interactive information sources (e.g., guided field trips, elementary school programs). The authors found that as a group, interactive sources were significantly more helpful than unidirectional ones. 


\section{Interactive Information}

As illustrated in the last two studies discussed, the stronger impact of interactive sources was perhaps the most consistent finding related to information preferences. Many studies have found a preference for one-on-one interactions as well as indications that personal relationships with agency personnel can be important in making judgments about information and actions (Jarrett et al. 2009, McCaffrey 2004, McCaffrey et al. 2011, McFarlane et al. 2007, McGee 2011, Nelson et al. 2004, Parkinson et al. 2003, Paveglio et al. 2009, Toman et al. 2008, Vogt et al. 2009, Winter and Cvetkovich 2010). For instance, McCaffrey (2004) found that having government or personal contacts was associated with lower concern about potential prescribed fire issues, including aesthetics, escape, and damage to trees, and with the perception that use of heavy equipment and herbicide application were more acceptable practices. In another study, agency outreach was mentioned by one-third of all respondents as a motivation to undertake defensible space actions, with a range of 15 to 63 percent across sites (McCaffrey et al. 2011).

Shindler et al. (2011) found that positive ratings of citizen-agency interactions were significantly correlated with greater acceptance of prescribed fire for both urban and rural Great Basin residents. In Toman et al.'s study (2006), of the three highest rated trustworthy sources (Smokey Bear, interpretive centers, and guided field trips) the last two sources, which are generally more interactive than Smokey Bear, also were clearly the most helpful with roughly 20 percent more respondents indicating they were helpful. In an assessment of how field tours influenced perception of fuels treatments, participants indicated that the opportunity to discuss the treatments with an expert was as valuable as the ability to see the land after treatment (McCaffrey et al. 2008). Similarly, Toman et al. (2008) found that personal interaction with Forest Service staff was the most valued aspect of postfire field tours and that after the tour more than 60 percent of participants indicated they were more supportive of fuels treatments and had more confidence in the Forest Service's implementation abilities. Although homeowner desire for one-onone interactions was predominantly focused on government consultations, several studies have found that, for at least some homeowners, neighbors and community leaders can be influential information sources (Agarwal and Monroe 2006, Brenkert-Smith 2010, McCaffrey et al. 2011). In Colorado, interacting one-on-one with full-time residents was a key information source for part-time residents, who saw their neighbors as the most knowledgeable individuals regarding mitigation options for their specific situation (Brenkert-Smith 2010).

Interactive communication also appears to be a factor in the quality of agency-community relationships. Studies have shown that increased agency-community interaction led to more positive feelings toward the agency (McGee 2011, Paveglio et al. 2009, Ryan and Hamin 2008). Conversely, Kumagai et al. (2004) found that after a fire those who either lived in a community that had little interaction with the state fire agency or did not receive up-to-date information during the fire were more critical of fire management.

\section{Caveats}

It is important to note that high usefulness or trustworthiness does not necessarily translate into desired outcomes. Although McCaffrey (2004) found that television received relatively high awareness and usefulness ratings, citing TV as an information source was associated with a 15- to 20-percent lower likelihood of undertaking defensible space measures. In contrast, neighborhood meetings (an interactive source), which had not been rated as a particularly useful information source, were associated with greater likelihood of undertaking defensible space measures. Although Absher and Vaske (2011) found generally high levels of trust in Forest Service information, they did not find a significant association between 
this trust and homeowners' reducing fuels on their property and found a negative association with making changes to their structure. Further demonstrating the complexity of determining the impact of information sources, Bright et al. (2007a) found that although the three agencies the study specifically asked about were all seen as reasonably credible, the Colorado Forest Service was seen as significantly more credible than either the Forest Service or the local fire department and that both the credibility of the information source and the clarity of the message were significantly related to how carefully people paid attention to fire information. However, the study also found that source credibility did not have an effect on how carefully people paid attention to firewise messages, though message clarity did. Only when a respondent paid careful attention was source credibility associated with increased likelihood of undertaking defensible space activities (Bright et al. 2007a).

\section{Other}

Finally, although most studies focused on pre-fire communication, a few studies indicate that preferred information sources may vary over time. Monroe and Nelson (2004) found that respondents preferred the news media for current fire information, but trusted agency sources more for information about reducing risk before a fire. Taylor et al. (2007) found that during fires demand increased for up-to-date, site-specific information from official sources, but the researchers also found that there were different information needs at different points during an event, that information sources were different for evacuees (evacuation centers were a good source), and that mass media were seen as inaccurate and not sufficiently local.

\section{Summary}

Overall, the research highlights the variability of the fire information sources people turn to and find helpful. However, four general patterns can be identified. First, no single source is the best - it will vary by location and by type of information needed. Second, the most used information sources are not necessarily the most trustworthy, and trustworthy information sources are not inherently useful. Third, government sources are generally a preferred information source and are often, but not always, highly rated. Finally, perhaps the most important characteristic in determining whether an information source is trusted and useful is if it allows for interactive exchange, as reflected in study respondents' preference for one-on-one consultations and local information sources. 
FUELS REDUCTION

What are the public's views

of fuels reduction methods and how do these views vary depending on citizens' location in the WUI or elsewhere?

In assessing public views of fuels reduction methods, most studies focus on prescribed fire and some type of thinning, generally mechanized. A few studies also examine grazing and use of herbicides or fuels reduction efforts after fires. Overall this body of work provides a picture of a public that generally supports the need for fuels reduction and helps identify some of the factors that influence support.

\section{Prescribed Fire and Mechanized Thinning}

Although more studies assess acceptance of prescribed fire, almost every study that asks questions about mechanical thinning or prescribed burning finds that more than 80 percent of respondents accept some level of use of each practice (Absher and Vaske 2006; Brunson and Shindler 2004; Kaval 2007; Lim et al. 2009; McCaffrey 2006, 2008a; McCaffrey et al. 2008; Shindler and Toman 2003; Shindler et al. 2009, 2011; Toman and Shindler 2006; Vogt et al. 2007; Walker et al. 2007). Several of the studies that found overall acceptance levels of more than 80 percent used the same two statements to assess acceptance levels: "a legitimate tool that can be used anywhere" and "a tool that can be used infrequently in selected areas" (Brunson and Shindler 2004; Shindler and Toman 2003; Shindler et al. 2009, 2011). The authors argued that the second, more qualified, statement also indicated acceptance as they felt the statement reflects the way that agencies tend to use both practices. For prescribed fire, respondents tended to be equally distributed between the unqualified and qualified acceptance responses ( $\sim 40$ percent each). For thinning, a greater proportion of respondents tended to choose

unqualified acceptance rather than the more qualified acceptance response (50 percent vs. 30 percent). Although these studies cover at least 15 different sites in the West and Midwest, what is most notable is not the differences between sites but the commonality of findings across sites (see Differences discussion).

A few exceptions have been found to these high acceptance levels, although even the exceptions tend to have more support than opposition. For instance, two studies found high levels of support for prescribed fire (more than 85 percent), but lower levels of support (57-68 percent) for mechanical thinning (Bowker et al. 2008, Monroe et al. 2006). Conversely, Toman et al. (2011) found high levels of support for thinning (83 percent) and lower levels of support for prescribed fire (66 percent). In the latter study, one of the five research sites did have lower levels of acceptance for both treatments, which the authors attributed to a sense that they were locally inappropriate given the community's steep landscape.

\section{Preferences}

Whether prescribed fire or mechanical thinning is the preferred practice varies: some sites show higher approval levels for thinning (Absher and Vaske 2006, Fried et al. 2006, Kent et al. 2003, Ryan and Wamsley 2008, Toman et al. 2011), others have relatively neutral preferences (Brunson and Shindler 2004, Walker et al. 2007), and others express higher approval rates for prescribed fire (Fried et al. 2006, McCaffrey et al. 2008). In several locations, participants preferred use of both practices together (Blanchard and Ryan 2007, Kent et al. 2003, McCaffrey et al. 2008, Vining and Merrick 2008).

The relative location of a treatment also appears to shape preferences. In general, studies have found a preference for use of mechanical thinning in more urbanized areas and for prescribed fire in less populated areas (Brunson and Shindler 2004, Knotek et al. 2008, McFarlane et al. 2007, Paveglio 
et al. 2011, Ryan et al. 2006). Similarly, the few studies that examine acceptability of letting naturally ignited fires burn found that acceptance was also dependent upon location, particularly in terms of risk to private property, with higher acceptance of fire use in more remote areas (Gunderson and Watson 2007, Kneeshaw et al. 2004b, McFarlane et al. 2007, Paveglio et al. 2011, Winter and Cvetkovich 2010). However, Toman et al. (2011) found an exception to this pattern with little difference between acceptance of use of prescribed fire in remote areas (66 percent) and around neighborhoods (62 percent) (although the latter did have higher proportions who judged it unacceptable rather than neutral). In a California study, respondents also took land ownership into account in assessing treatment preferences, with prescribed fire the preferred practice for use on National Park Service lands and slightly stronger preferences for use of mechanical harvest (preferably in conjunction with prescribed fire) on Forest Service and private lands (McCaffrey et al. 2008).

\section{No Action}

When provided as an option, "no action" consistently is the least preferred choice (Bright and Newman 2006, Daniel 2006, Kent et al. 2003, McCaffrey et al. 2008, Olsen and Shindler 2010, Ryan and Wamsley 2008). In Massachusetts, Blanchard and Ryan (2007) found only moderate support for no action, although there was more support for active management, particularly prescribed fire, on public land than on private land. (This study also found significantly lower levels of support for prescribed burning on public land among those who leased cottages on the public land.) Daniel (2006) found a preference for salvage and re-planting treatments over natural regeneration for sites disturbed by a blowdown, with long-term future conditions having a larger impact on preferences than near-term future conditions. However, Olsen and Shindler (2010) found that while a large percentage were supportive of salvage logging after a fire, a majority also supported taking no action-a combination that the authors concluded likely reflected recognition that across a large landscape certain treatments will be more appropriate than others for certain areas.

\section{Grazing and Herbicides}

Fewer studies consider public acceptance of alternative fuels management practices, including livestock grazing and use of herbicides. Where studied, however, grazing has been found to have an acceptance rate ( $\sim 80$ percent) fairly comparable to that of prescribed fire and mechanical thinning (Brunson and Shindler 2004, Shindler et al. 2011). In rural areas the largest proportion of respondents find the practice fully acceptable (generally more than 60 percent) (Brunson and Shindler 2004, Shindler et al. 2011) while urban respondents are more likely to indicate qualified rather than full acceptance (McCaffrey 2008a, Shindler et al. 2011).

Much lower acceptance levels are found for use of herbicides, with the largest proportion of respondents finding their use unacceptable (Bowker et al. 2008, McCaffrey 2008a, Monroe et al. 2006, Toman et al. 2011). In Colorado, Kent et al. (2003) found chemical treatment preferred over prescribed fire in their initial interviews, but less preferred in follow-up interviews conducted after the Hayman Fire. Shindler et al. (2011) found that, along with chaining trees, use of herbicides had the lowest approval of offered treatments, although higher acceptance levels were found for rural respondents as compared to urban.

\section{Considerations}

Level of fire risk. Interestingly, few studies specifically addressed how level of risk influenced views of fuels treatments on public lands; rather, most studies that examined this dynamic looked at the influence of risk perception on homeowner defensible space decisions. Although a comprehensive assessment of defensible space studies is beyond the scope of this project, the research suggests that while recognizing 
high risk is necessary, it is not sufficient to engender proactive behaviors (McCaffrey 2008b, McCaffrey et al. 2011). As in other hazard research, defensible space research has shown that multiple factors are at work. For example, Winter et al. (2009) found that high fire risk was one of three factors shaping acceptance of mandatory defensible space standards. The fact that few studies specifically discuss ties between level of risk and fuels treatments also is likely a byproduct of the fact that most were conducted in areas with high fire risk, in essence turning it into a constant. The high levels of understanding of fire risk and fire ecology found in studies (see Knowledge discussion) also suggest that high fire risk is assumed in most fuels treatments discussions.

The few studies that do explicitly discuss relationships between fuels treatment support and level of risk indicate that a high level of risk is an important component of support for fuels treatment. Most relevant is a study that examined how four contextual factors, including level of fire risk, influenced acceptance of three management actions (Bright and Newman 2006). The study found that for all three sites (Colorado, southern Illinois, and Chicago) current conditions were by far the most important factor for all treatments: higher fire hazard led to higher support for prescribed burning and mechanical thinning and lower support for no artificial treatments. Of the remaining three contextual factors, location of treatment and wildfire history had some influence on support while primary use (outdoor recreation vs. commercial activities) had limited influence. A few other studies also found a significant relationship between level of perceived wildfire risk and treatment acceptance. Fischer (2011) found that private forest owners with higher levels of concern about a fire causing structure loss or affecting other aspects of their property were more likely to treat portions of their land. In another study, perception of high local fire risk was associated with higher acceptance of salvage logging, selective timber harvest, and hand thinning (McCaffrey 2008a).
Finally, on Long Island, Ryan and Wamsley (2008) found stronger support for fuel zones around forests from respondents in higher risk locations.

Forest Health. Forest health is generally a parallel and sometimes more dominant consideration than reducing fire risk in shaping acceptability or approval of treatments (Bowker et al. 2008, Burns and Cheng 2007, Fischer 2011, McCaffrey et al. 2008, McFarlane et al. 2007, Paveglio et al. 2011, Vining and Merrick 2008, Walker et al. 2007). A national survey found the highest level of concern expressed by respondents was for the statement that "fire management programs consider long-term forest health" (64 percent concerned and 14 percent slightly concerned; Bowker et al. 2008). McCaffrey et al. (2008) found that forest health and fire hazard were the two most important considerations in determining treatment preferences, with 80 percent of respondents indicating that each was very important. In Oregon, forest owners who were more concerned about wildlife and ecological values were one and a half times more likely to have undertaken treatments on their land than those who were less concerned (Fischer 2011). In analyzing participant views of different fuels reduction scenarios, Vining and Merrick (2008) found that ecological factors were the second most frequently mentioned topic (after safety) and that ecological benefits were mentioned more frequently than negative ecological outcomes. In a study focused on identifying the different ways that engaged citizens think about active forest management, Burns and Cheng (2007) found that consideration of forest health was the most common lens through which opinions of forest management were formed.

Potential Treatment Outcomes. Although not uniform across studies, risk of escape is generally the primary concern raised about prescribed fires (Blanchard and Ryan 2007, McCaffrey 2006, McFarlane et al. 2007, Monroe et al. 2006, Shindler et al. 2009), while erosion is usually the dominant 
concern with mechanical treatments (Blanchard and Ryan 2007, Shindler et al. 2009). Wildlife is often the next highest concern for both treatments, followed by aesthetics. Concern about smoke varies but is generally one of the lowest ranked concerns (see Smoke discussion) (Blanchard and Ryan 2007, Bowker et al. 2008, Jacobson et al. 2001, Lim et al. 2009, McCaffrey et al. 2008, Ryan and Wamsley 2008, Shindler et al. 2009).

Potential treatment outcomes are not always seen as a reason not to use the practice. In fact, study participants often indicate that they expect the treatment to improve rather than detract from a particular value (e.g., restore natural conditions, improve habitat or scenery) (Blanchard and Ryan 2007, Brunson and Shindler 2004, Fischer 2011, McGee 2011, Toman et al. 2004, Vaske et al. 2007, Vining and Merrick 2008, Winter et al. 2006). The influence of outcomes on acceptance appears to be shaped by local context as studies generally find inconsistent associations between a specific outcome and support (or lack thereof) for a treatment: when there are significant associations, they vary across studies and across study sites. For example, Winter et al. (2006) found that only two of seven outcome variables were fairly consistently associated with acceptance across treatments sites: likelihood of escape was negatively associated with prescribed fire acceptance across all four sites and likelihood that a practice was cost-effective was positively associated with approval for prescribed fire, mechanical fuels reduction, and defensible space for three of four sites. However, the remaining five outcomes were generally not significantly associated with acceptance and when significant relationships existed, they varied by both site and practice.

\section{Predictors}

While certain potential treatment impacts, on occasion, are significantly associated with treatment approval, the two variables most commonly associated with acceptance of fuels treatments are knowledge of a practice, and trust in managers to implement it.

Knowledge/Familiarity. Knowledge was the factor most commonly associated with treatment acceptance; higher levels of knowledge or familiarity with a practice were significantly associated with higher levels of acceptance for the practice (Absher and Vaske 2006, Blanchard and Ryan 2007, Brunson and Shindler 2004, McCaffrey 2004, Parkinson et al. 2003, Shindler and Toman 2003). Absher and Vaske (2006) found that a psychological index based on three variables familiarity with the practice, views on aesthetics, and effectiveness - was a very strong predictor (explaining 39 percent of the variance) of approval of prescribed fire and thinning. The association between knowledge and acceptance also can be seen in the impact of field tours. For instance, in California, tours of fuels treatments had a positive effect on views of prescribed fire and a strong negative effect on views of untreated landscapes but did not affect views of mechanical treatments (McCaffrey et al. 2008). In two separate Oregon studies, field tours were found to increase support for both thinning (Toman et al. 2008) and prescribed fire (Toman et al. 2004, 2008) .

Higher knowledge levels are also associated with less concern about specific outcomes, particularly for prescribed fire (see also Smoke discussion). In Massachusetts, some knowledge of prescribed fire was associated with less concern about aesthetics, and having a great deal of knowledge was associated with lower concern about the effects on animals and their habitat (Blanchard and Ryan 2007). In addition, those with experience with wildfire had lower concern about several risks of prescribed fire (i.e., impacts of smoke, potential to escape, and damage to wildlife habitat), which the authors suggested was because those who had witnessed a wildfire developed a better understanding of how fires burn than those who had never seen a wildfire (Blanchard and Ryan 2007). On Long Island, the same study found respondents 
who were more familiar with prescribed fire were more willing to allow its use on private land, a location where use of prescribed fire is less likely to be seen as appropriate (Ryan and Wamsley 2008). In Nevada, McCaffrey (2004) found that those who had read prescribed burning educational materials were more likely to think it improved wildlife habitat and diversity, and less likely to agree that prescribed fire was unnecessary, that they did not like the appearance afterwards, or that smoke caused problems for a member of their household.

Trust. Studies have also found that public acceptance is influenced by perceptions of agencies and the individuals who are implementing the practice, specifically whether they are competent and trusted (Gunderson 2006, McCaffrey 2006, Monroe et al. 2006, Olsen and Shindler 2010, Toman et al. 2011). Several studies have found statistical relationships between trust in agencies to responsibly carry out a practice and treatment acceptance or approval, with higher levels of trust associated with higher levels of acceptance (Fried et al. 2006, Shindler et al. 2011, Shindler and Toman 2003, Vaske et al. 2007, Winter et al. 2006). Toman et al. (2011) found significant correlations between acceptance and both agency trust and confidence (a form of trust) in agency managers to implement a specific treatment. However, they found that only treatment-specific confidence was significant in predicting acceptance, often in a very substantial way: a one-unit increase in confidence (from moderate to full) predicted an increase in acceptance of thinning by a factor of 6.2 , of using prescribed fire in neighborhoods by a factor of 4.6, and of using prescribed fire in remote areas by a factor of 2.7. Another study focused on Great Basin rangelands similarly found that, for both urban and rural respondents, the most highly correlated factor in acceptance of a treatment was confidence in agency managers' ability to implement a specific treatment (Shindler et al. 2011).

\section{Summary}

Overall, results clearly show that prescribed fire and mechanical thinning are, at some level, acceptable management practices for more than three-quarters of the public. While concerns about location and potential treatment outcomes are considered in determining acceptability, except for smoke (see Smoke discussion), these factors do not appear to be primary determinants of acceptance, but more contextual constraints. Instead levels of understanding of a practice, particularly its ecological benefits, and level of trust in those implementing a practice appear to be the primary variables shaping acceptance. These findings, combined with findings that 1) no action is consistently the least preferred alternative, and 2 ) forest health is an equal or greater consideration as fire risk reduction, suggest that there is greater public support for active rather than passive land management in achieving ecological health and fire risk reduction goals. 


\section{SMOKE}

What is the public's understanding of smoke effects on human health, and what shapes the public's tolerance for smoke?
The public's response to smoke from wildfire and prescribed fire has been addressed only tangentially in social science research. Only one study, Weisshaupt et al. (2005), had a significant focus on smoke while in a number of others, smoke was mentioned as just one of many considerations in how study participants thought about fuels management (Bell and Oliveras 2006, Carroll et al. 2004, McFarlane et al. 2007). For the majority of studies, smoke issues were examined through one to three specific questions, generally in relation to prescribed fire, among a larger set of questions about fire and fuels management (Blanchard and Ryan 2007, Bowker et al. 2008, Brunson and Evans 2005, Brunson and Shindler 2004, Jacobson et al. 2001, Loomis et al. 2001, McCaffrey 2004, McCaffrey et al. 2008, Ryan and Wamsley 2008, Shindler and Toman 2003, Toman et al. 2004, Toman and Shindler 2006, Vogt et al. 2005).

The research suggests that while smoke is an issue, it is not a major concern for the majority of the public. Indications are that when smoke is an issue, it is primarily because of health reasons. A review of four studies found that approximately 30 percent of respondents had a household member with a health issue affected by smoke (McCaffrey 2006). Similarly, in several other studies, 20-40 percent of respondents indicated relatively high levels of concern about prescribed fire smoke due to its potential health impacts (Brunson and Evans 2005, Jacobson et al. 2001, Loomis et al. 2001, Ryan and Wamsley 2008,
Shindler and Toman 2003). Other studies that asked only a general question about smoke from prescribed fire found a similar percentage of respondents who indicated smoke was a major consideration or concern (Bowker et al. 2008, Brunson and Shindler 2004, McCaffrey et al. 2008). While this concern about smoke in general is not inherently due to health reasons, the consistency in percentages suggests that vulnerability to health impacts is a likely explanatory factor. Together these findings suggest that for roughly one-third of households smoke is a major issue, but that for others smoke is less important. This is reflected in the fact that a number of studies find that smoke and health issues are generally not seen as a reason to avoid using prescribed fire and that higher levels of concern are routinely expressed about other issues - including risk of escape, wildlife effects, erosion, aesthetics, human and property safety, and water supply (Bell and Oliveras 2006, Blanchard and Ryan 2007, Brunson and Evans 2005, Carroll et al. 2004, Jacobson et al. 2001, McCaffrey et al. 2008, Toman and Shindler 2006).

Generally, more knowledge of and/or experience with prescribed fire are associated with less concern about smoke (Blanchard and Ryan 2007, Loomis et al. 2001, McCaffrey 2004, Ryan and Wamsley 2008, Weisshaupt et al. 2005). In particular, recognition of the ecological benefits of prescribed fire appears to make smoke more acceptable to the majority of people (Shindler and Toman 2003, Weisshaupt et al. 2005). An interesting variant on ecological benefits was found in Weisshaupt et al.'s study (2005), which found that the source of smoke mattered: members of an antismoke group found smoke from agricultural burning unacceptable as benefits accrued only to the farmer, but as participants learned more about the ecological benefits of a burn, they became more willing to tolerate smoke from prescribed burns on public lands because the benefits accrued to multiple parties. 
There also appears to be a general attitude among study participants that individuals who choose to live near natural areas need to accept living with smoke (Jacobson et al. 2001, McCaffrey 2006, Weisshaupt et al. 2005). Smoke from prescribed fires is also preferable to that from wildfires as it is seen as more manageable and allows for advance warning for those with health concerns (McCaffrey 2006, Weisshaupt et al. 2005). However, this association may not influence acceptance of prescribed fire use; Winter et al. (2006) found that while the majority of respondents agreed that prescribed fire would likely result in less smoke in the long-term, this belief was significantly associated with increased acceptance of prescribed fire in only one of four sites.

Brunson and Evans (2005) re-surveyed a Utah population whose attitudes toward fire had been studied before an escaped prescribed burn directly impacted the respondents. Few significant changes in attitudes were found after the escape except in relation to smoke, where significant increases were found for concern about: 1) increased smoke levels, 2) effects of smoke on public health, and 3) smoke management. Despite these increased smoke concerns, the authors found no significant change in the percentage (13 percent) that agreed that "because of smoke, prescribed fire isn't worth it" (Brunson and Evans 2005). Another repeat study by Shindler and Toman (2003) found significant changes in concerns about smoke from 1996 to 2000; fewer respondents agreed that "smoke levels from fire are not a problem for me or my family" (from 76 to 61 percent) and that "smoke levels are acceptable if it results in a healthier forest" (from 68 to 58 percent). It is worth noting that despite these changes, the majority still indicated that given the potential ecological benefits of fire, smoke was acceptable.
In a national survey, Bowker et al. (2008) found racial/ ethnic differences, with high levels of concern about smoke expressed by roughly twice as many African American and Hispanic as Caucasian respondents. Gender was also significant in two studies; women were more concerned about smoke than were men (Lim et al. 2009, Ryan and Wamsley 2008). Although multi-site studies found some variability in smoke responses between locations, the differences appear to have less to do with regionality than with differences in local fire experience (See Differences discussion).

Finally, only two studies addressed public response to wildfire smoke. Kneeshaw et al. (2004b) found that individuals were less willing to accept less aggressive responses (such as let burn) when the actions contributed to poor air quality. Thapa et al. (2004) found that smoke concerns (health problems, automobile accidents, and general smoke) led some destination vacationers ( 5 percent) to cancel their trip and roughly one-third to change their destination.

\section{Summary}

Studies thus far suggest that smoke is not a significant barrier to the use of prescribed fire for a majority of the population and that a desire to improve forest health and/or reduce future fire risk tends to outweigh smoke concerns. However, findings also suggest that for a sizeable portion of the population - roughly a third of households - smoke is a major issue due to health concerns. For this segment smoke is likely a more dominant concern because of its implications for the health and well-being of family members. For individuals potentially affected, understanding how smoke issues are addressed in fire and fuels management will continue to be a highly salient issue. 


\section{RESPONSIBILITY}

What are homeowners' views of their responsibilities for home and property protection and mitigation (e.g., defensible space)?
A central difficulty with assessing findings relevant to this question is that within the fire management community, and in comments from the public, property protection and mitigation are often lumped together as one item. In some cases what is being referenced is active protection during a fire and in others "protection" includes notions of mitigation. This confusion is also reflected in research studies which when assessing public views of responsibility and protection do not tend to clearly address how these views may vary depending on which point in the fire management cycle is being considered.

Surveys highlight the difficulty of distinguishing between views of responsibility for mitigation and protection but begin to suggest that the public does not inherently interpret the phrase "protection from wildfire" to mean only protection during a fire. While surveys to date do not provide clarity about who is seen as responsible for what activity, the findings do suggest that the responsibility is seen as shared. For instance, in response to a question about whether private landowners or public agencies were responsible for protecting homes near a forest from wildfire, Absher et al. (2009) found that overall, respondents did not agree with any of three distinct statements that homeowners, or the community fire department, or the relevant government forest agency was responsible for protecting homes from a wildfire. McCaffrey and Winter (2011) asked respondents in California, Montana, and Florida who (homeowners versus firefighters) was "most responsible for protecting private property from wildfire" and found that the majority of respondents put more (35 percent) or all (23 percent) of the responsibility on homeowners while a quarter indicated it was an equal responsibility. In a different approach, Winter and Cvetkovich (2010) asked respondents to divide up 100 responsibility points for reducing the fire risk in the San Bernardino Mountains. The average points assigned were not markedly far apart: in particular only seven responsibility points separated the top four ranked entities: the Forest Service (which manages most of the land in the area), followed by Calfire (the state fire agency), the respondent's household, and the local fire department.

Qualitative studies further suggest that responsibility is seen as shared, particularly in terms of mitigation. When discussing fire management, interview and focus group participants routinely bring up the notion of shared responsibility. In these discussions, each landowner, whether private or public, is seen as primarily responsible for taking care of his or her property (Brenkert-Smith et al. 2006, Cohn et al. 2008, Kent et al. 2003, McCaffrey et al. 2011, Paveglio et al. 2011, Vining and Merrick 2008, Vogt et al. 2009). The sense that homeowners see themselves as responsible for mitigating fire risk on their property is further supported by the fact that most studies on defensible space find at least two-thirds of homeowners in areas with a significant fire risk are undertaking a variety of fuels treatments and other defensible space measures on their property, which demonstrates a sense of responsibility (e.g., Absher and Vaske 2006, Fischer 2011, McCaffrey 2008b, McCaffrey and Winter 2011, McGee 2011, Monroe and Nelson 2004, Shulte and Miller 2010, Winter and Cvetkovich 2010).

\section{Adjacent Land}

Informing the discussion of shared responsibility is recognition that the risk is shared: that as fire does not recognize property lines, to be most effective fuels reduction measures often need to occur across ownership boundaries. A number of studies found 
that concern about actions on adjacent properties, whether the land was privately or publically owned, was an important consideration in whether individuals believed they could effectively create defensible space (Brenkert-Smith 2011, Fischer 2011, Kent et al. 2003, Martin et al. 2007, Paveglio et al. 2011, Shiralipour et al. 2006, Shulte and Miller 2010, Weisshaupt et al. 2007, Winter and Cvetkovich 2010). This concern may or may not lead to increased actions on one's own property. Fischer (2011) found that concern about conditions on nearby public land was associated with private forest owners' being more likely to undertake fuels treatments on their land, while concern about conditions on nearby private property had no effect. Brenkert-Smith et al. (2006) found that homeowners felt that risk on their property was their responsibility but that they also were concerned about the threat from adjacent unmitigated private land and that, in response to this concern, neighbors had often worked together to reduce fuels across land ownerships. Concern about mitigation activities on adjacent lands was most frequently raised in relation to adjacent federal lands with a sense that the government was responsible for making sure "its practices do not negatively affect the surrounding citizens" (Weisshaupt et al. 2007). Concern about adjacent public land was also related to a sense of fairness; if the government asks residents to take care of their property, then it should be doing the same on its land (Winter et al. 2009).

In some cases, recognition of the shared fire risk across land ownership may create support for regulation. In New York and Massachusetts, Ryan et al. (2006) found little support for requiring homeowners to remove vegetation, but several other studies found support for such requirements (Bowker et al. 2008, Vogt et al. 2009, Weisshaupt et al. 2007). Two-thirds of respondents to a national survey agreed that "where wildfire is common, homeowners should have to follow government guidelines to manage for wildfire risk." Levels of agreement were higher amongst Caucasians (73 percent) and lower among African
Americans (54 percent) and Hispanics (57 percent) (Bowker et al. 2008) (see Differences section). In Vogt et al.'s study (2009) one of the three factors that made mandatory programs potentially justified was if individual noncompliance put others at risk. The other two factors were a recognized public safety role for local government and high fire risk: this last factor may explain the low support for regulation in Ryan et al.'s study (2006), in which respondents did not see a high fire risk.

\section{Choice}

An argument underlying views of shared responsibility is the notion of choice - that if people choose to live in high fire risk areas they must also be willing to accept that risk and the associated responsibility, including financial obligations, for their own protection (Bowker et al. 2008, McCaffrey 2004, Paveglio et al. 2011, Weisshaupt et al. 2007). Two-thirds of respondents in a national survey agreed that those "who choose to live near forests or rangelands should be prepared to accept the risks of wildfire" (Bowker et al. 2008).

\section{Education and Fire Planning}

Research has shown broad support for the idea that relevant government agencies have some responsibility for providing educational materials and advice to homeowners about reducing risk (Cohn et al. 2008, Jarrett et al. 2009, McCaffrey et al. 2011, Paveglio et al. 2009, Weisshaupt et al. 2007, Winter et al. 2009). Although responsibility for fire management planning is seen as primarily an agency responsibility, survey respondents expressed a clear desire that the public should be kept informed about management activities and involved in the planning process at some level (Cohn et al. 2008, McFarlane et al. 2007, Paveglio et al. 2011, Ryan et al. 2006, Ryan and Hamin 2008, Toman et al. 2008). In Massachusetts, the statement that "public education and outreach should be part of a fire hazard reduction program," received the most positive rating in the survey, followed by support for residents' involvement in planning focus groups and 
advisory committees (Ryan and Wamsley 2008). On Long Island the study found that 87 percent agreed "a lot" to "a great deal" that public education and outreach should be included in a fire hazard reduction program, while only 26 percent showed that level of agreement in relation to state and local officials' having sole responsibility for developing fire hazard reduction programs (Ryan and Wamsley 2008).

\section{Protection During a Fire}

Only a few studies had findings specific to expectations of protection during a fire. Gordon et al. (2010) found that fire risk in West Virginia was seen mostly as a mining company's responsibility, as the majority of fires were on corporate land. When a fire was not on mining land, then respondents felt that the state was responsible for protecting forestland and the local fire department was responsible for taking care of homes. In Washington state, Paveglio et al. (2011) found that participants felt that agencies should focus primarily on managing public land, not on protecting nearby houses (Paveglio et al. 2011). Ryan et al. (2006) found that respondents in Massachusetts and especially Long Island had a strong belief that the local fire department would respond quickly to protect homes. In two Colorado communities, expectations of protection differed based on whether the community had a fire department. The community that had a fire department focused on emergency response planning over mitigation, while the community without local protection focused more on mitigation, partly in recognition that firefighting resources were likely to be inadequate and also as a way to increase the likelihood of firefighters' choosing to protect their homes (Brenkert-Smith 2011). When asked what they would do if there were no firefighting services, many participants in Collins and Bolin's study (2009) indicated they would likely undertake different actions, such as building a smaller house or undertaking more mitigation. Finally, McCaffrey and Winter (2011) surmised that respondents were not assuming firefighter protection given that when asked why they took undertook mitigation on their property, homeowners indicated that their primary reason was the likelihood it would decrease the risk of home ignition and increase structural survival with or without protection.

\section{Summary}

Research shows a clear public view that responsibility for mitigating fire risk is shared by all landowners. Both a sense of fairness and recognition that actions on adjacent properties can affect one's fire risk shape this opinion. Beyond the view that the government is responsible for taking care of its property, there is also sentiment that the government has a responsibility to provide information on mitigating risk on private land. Finally, the confusion over how people think about the term "protection"-whether it is just a reference to active protection during an event or includes more passive protection from mitigation actions taken before a fire - is worth noting and suggests an area that future research may want to address more carefully. 
HUMAN HEALTH AND SAFETY

What role does human health and safety play in the public's perceptions of fire and fire management?

No published study could be found that directly addresses the role of health and safety in the public's perceptions of fire and fire management, though several studies did address it tangentially. Overall, these studies begin to suggest that human health and safety issues underlie most assessments of fire management - from fuels management to firefighting - but that they are more an implicit rather than an explicit consideration. At a general level, McFarlane et al. (2007) found that public safety and protection was one of the three main topics raised when discussing the goal of fire management and that participants were open to letting some fires burn provided safety and infrastructure issues had been accounted for. Flint (2007) found that risk concerns fell into two distinct categories: immediate risks to property and safety, and more general risks to community and ecological well-being. In a survey of WUI residents in four western states, Brunson and Shindler (2004) found that slightly under half of respondents indicated great to moderate concern about human safety in relation to prescribed fire.

In terms of mitigation, an analysis of individual assessments of different fuels management scenarios found that safety was the most frequently raised topic, brought up by two-thirds of participants. Of note is that safety concerns, such as prescribed fire escapes, were mentioned only slightly more often than safety benefits of fire management, such as preventing large wildfires (Vining and Merrick 2008). Vogt et al. (2009) found that mandatory defensible space programs were seen as acceptable when three factors were present: wildfire risk was high, individual noncompliance puts others at risk, and local government was seen to have a public safety role. The study also found that homeowners supported emphasizing the community health and safety benefits of defensible space practices. In many ways, health and safety concerns emerged most concretely in relation to use of prescribed fire, in terms of safety concerns related to escape and to its use near structures (see Fuels Management discussion) and about smoke, which is primarily a health issue (see Smoke discussion).

In relation to experiencing a fire, findings from a recent and not yet published survey of homeowners in four communities affected by wildfires in 2010 indicate that health and safety are key concerns during an event (Steelman and McCaffrey 2010). When respondents were asked how important certain considerations were in judging the fire management decisions made during the fire, firefighter safety and community/resident safety were the two most important considerations in all four sites. Finally, a Utah study found that the top three concerns about potential fire impacts were related to public health and safety: deteriorated public water supply, damage to private property, and risk to human safety (Brunson and Evans 2005).

\section{Summary}

Although findings are too limited to provide a coherent picture, they suggest that members of the public put a priority on human health and safety and that, at a certain level, this consideration underlies the entire fire management discussion. However, findings also indicate the public recognizes that protecting health and safety is not always straightforward and that sometimes current fire management practices that are a cause for safety concerns may also lead to future safety benefits. 


\section{cost}

What are the public's views on the role and importance of costs in wildfire incident response decisions?

Until recently, the focus of the majority of fire social science research has been on pre-fire mitigation efforts. Thus, it is not surprising there is little data specific to the question of the public's views of costs related to wildfire incident response decisions (i.e., firefighting). By necessity, the following section takes a slightly broader consideration of research findings and looks at the public's views of cost during any aspect of the fire management process.

As with health and safety, the most directly relevant information is from a recent and still to be published Joint Fire Science study (Steelman and McCaffrey 2010) that surveyed homeowners in four communities affected by wildfires in 2010. Homeowners in the four communities were asked how important it was to receive certain types of information during a fire and how important certain considerations were in their judgments about management decisions during the fire. In all four sites, firefighting cost was the least important information and consideration to respondents. The two most directly affected communities had lower average judgments about cost importance than the two less affected communities, suggesting that fire directly impacting an area results in less concern about cost.

The remainder of relevant research findings focus on pre-fire costs and suggest that cost is a more important consideration before an event than during it. In a national survey, a majority of respondents indicated they were concerned that taxpayer costs were "considered when developing fire management programs." The study found significant differences between different race/ethnicity groups with higher proportions of African Americans showing concern (73 percent) than Hispanics (44 percent) and Caucasians (31 percent) (Bowker et al. 2008). When respondents analyzed different fuels reductions scenarios, Vining and Merrick (2008) found that economic concerns were the fourth most frequently mentioned topic (by 35 percent of respondents), with the focus roughly equally split between concerns (e.g., costs of implementing the treatment) and economic benefits (e.g., reduced future firefighting costs).

Several other studies found that cost-effectiveness of an action, particularly its ability to reduce future wildfire costs, was an important consideration. McCaffrey et al. (2008) found that almost 80 percent of respondents indicated that concern about cost effectiveness was a somewhat to very important factor in determining their treatment preferences. In focus groups in Florida, Michigan, and California, cost considerations (e.g., costs of an escape, physical resources to do the job) were frequently brought up (Winter et al. 2002). In a follow-on survey, at least half of respondents at each site (the three original states plus Missouri) thought that mechanical harvesting (5376 percent) and prescribed fire (50-80 percent) would save money by reducing the cost of fighting a future wildfire, rating it a "very likely" or "certain" outcome (Winter et al. 2006). More importantly, the belief that saving money was a likely outcome of a fuels management method was positively associated with its acceptance in all sites except Missouri. The notion that it is better to pay now to reduce fuels than pay more later to fight fires was also a consistent theme in ten focus groups held around Missoula, MT, and Spokane (Weisshaupt et al. 2007). In a survey of Colorado homeowners examining willingness to pay for prescribed fire, thinning, and fire suppression, Kaval et al. (2006) also found support for reducing fuels now, and showed that those who had conducted defensible space activities were more willing to pay for thinning on public lands (Kaval and Loomis 2008). 
Other studies where cost was raised addressed potential local economic impacts and defensible space costs. Concerns about economic impacts were fairly general and centered on impacts of experiencing an event. In a re-survey of Utah study respondents after a nearby escaped prescribed fire, concern about economic loss of usable timber increased from the pre-escape responses (from 32 to 51 percent) (Brunson and Evans 2005). Arvai et al. (2006) found significant differences in beliefs about the economic effects of a future fire between members of two Canadian communities, one that had recently been affected by a fire and one that had not. Residents of the unaffected community were more likely to believe that potential economic impacts would be negative and severe and that recovery would take longer. Conversely, Rasmussen et al.'s study (2007) found that tribal members in the Pacific Northwest tended to focus on the positive economic aspects of fire, frequently mentioning the economic opportunities of fire management, such as fuels management, firefighting, stewardship contracting, and biomass removal. Finally, several studies have found that property owners cite economic costs as a key obstacle to adoption of fire mitigation activities, particularly for more expensive activities such as installing new roofs and increasing water supply (Absher et al. 2009, Collins and Bolin 2009, Martin et al. 2007, McFarlane et al. 2007, Winter et al. 2009). However, reflecting the previous discussion about cost-effectiveness, two studies also found that belief that creating defensible space was a cost-effective activity was associated with more positive views about defensible space (McCaffrey 2004, Winter et al. 2006).

\section{Summary}

Study findings are too few to draw clear conclusions about how cost factors into public assessments of fire management, let alone incident response. The one study with findings specific to incident response suggests that during an event, other considerations are more important than cost. However, studies suggest that before an event, cost is a more important consideration, primarily in terms of the long-term costeffectiveness of planned actions and the feasibility of defensible space activities. 


\section{DIFFERENCES}

\section{To the extent that information is available, how do findings differ among ethnic and cultural groups, and across regions of the country?}

It is commonly believed that people living in different regions of the country, or with different socio-demographic characteristics, or from different ethnic or cultural groups respond differently to fire management issues. However, analysis of social science research findings over the past 10 years indicates that geographic and socio-demographic differences are rarely key explanatory factors where fire management knowledge, attitudes, or actions are concerned. A more limited body of research, on the other hand, suggests that ethnic group membership and harder-to-measure differences such as culture and worldview may be more meaningful.

\section{Geographic Differences}

Many studies have explicitly included geographic variation as part of their design. Notably, the most consistent finding across these studies is that they detected much less variation than expected (Nelson et al. 2004; Shindler et al. 2009; Toman et al. 2006, 2011; Vining and Merrick 2008). Where geographic variation has been found, it either has generally been too small to be meaningful or was seen to reflect specific local contextual factors, such as ecological conditions, regulations, building styles, agencycommunity interaction, or specific historical events (Bowker et al. 2008, Brunson and Shindler 2004, Kneeshaw et al. 2004a, McCaffrey et al. 2011, Mendez et al. 2003, Ryan 2010, Shindler et al. 2009). For example, one study found variation in responses across four states, but an examination of findings across papers (e.g., Winter et al. 2002, 2006) indicates that the variation is likely a reflection of local practices and experience: in California, where defensible space ordinances are very active, respondents were supportive of defensible space; Florida, where prescribed fire was most common, had the highest level of acceptance for prescribed fire; and Michigan respondents, who had experienced a damaging escaped prescribed fire, were most knowledgeable about fire damage and evacuation. Despite these differences, the authors found that the three strongest predictors of treatment acceptance (trust in the responsible agency, attitude toward treatment, and personal importance of a treatment) were consistent across regions of the country (Winter et al. 2002, 2006).

One common geographic variable thought to influence views is urban or rural residency. Evidence for this view is limited because most studies have been conducted in WUI areas, but the evidence available suggests that assumption may not be meaningful. A study by Shindler et al. (2011) provides an example of how urban/rural residency status seems important in some instances but not in others: while they found a number of differences between urban and rural respondents' views of rangeland management in the Great Basin, differences were less distinct for wildfirerelated issues. Although rural respondents tended to see primary threats to rangelands as due to ecological processes while urban residents were more likely to see the threats due to human actions, roughly the same percentage (62-65 percent) of respondents from each group saw wildfire as a threat. In addition there were no significant differences between the two groups on acceptance of prescribed fire, although rural residents had higher acceptance levels for felling trees, livestock grazing, and using herbicides.

Other studies found few notable urban/rural differences. For example, Bright and Newman (2006) surveyed homeowners in the Front Range of Colorado (with recent fire experience), southern Illinois (low fire experience), and metropolitan Chicago (no 
wildfire experience). They found that differences between locations were few and minor, and primarily a matter of the degree of importance in secondtier considerations (wildfire history and location of fire) in judging treatment acceptability. For all three options (mechanical harvest, prescribed fire, and no treatment), the current condition or risk level was the most important factor influencing acceptance in all three locations: if wildfire risk was high, then both prescribed burning and mechanical treatment were more acceptable and no treatment less so. Brunson and Evans (2005) also purposively chose a sample of both urban and rural respondents in Wasatch County, Utah, and found no significant difference in responses. Weisshaupt et al. (2007) found that while Spokane, Missoula, and rural residents all tended to put primary responsibility for mitigating fire risk on homeowners, Spokane residents (the most urban of the sample) tended to put a bit more responsibility on government. Finally, McCaffrey (2008b) found the inverse of one common assumption related to urban/ rural differences: members of focus groups who lived in town (in areas unlikely to be directly affected by a fire) actually had higher assessments of the area's wildfire risk than those who lived in the interface or intermix. The author concluded that this inverse response reflected two dynamics: self-selection (riskaverse individuals chose not to live in high fire risk areas) and a cost-benefit dynamic previously identified in risk perception research, whereby the higher the perceived benefits of exposure to a potential hazard (e.g., living in the forest), the lower the perceived risk from the hazard. While these studies provide somewhat mixed evidence, they suggest that the urban versus rural distinction is not a consistently useful explanation for understanding differences in public response to wildfire. Indeed, the distinction appears to be more meaningful in shaping judgments of the appropriateness of different treatments in urbanized versus more rural areas (see Fuels Treatment discussion).

\section{Socio-Demographic Differences}

When discussing socio-demographic factors, studies address two general categories - standard demographic measures (age, income, education level, and gender) and residential characteristics such as length of residence and type of residents (permanent or seasonal). The most apparent dynamic for both of these measures is how often these variables are found to be of no significance in relation to key variables, particularly support or approval of a treatment (Fischer 2011, Fried et al. 2006, Jarrett et al. 2009, Lim et al. 2009, Mendez et al. 2011, Shindler and Toman 2003, Toman et al. 2011). In addition, a number of surveys did not even report demographic findings, likely because they were either not significant or not meaningful. Furthermore, of the few studies that report significant relationships between fire-related attitudes and behavior, and education, income, age, or length of residence, relationships are not consistent between studies and no meaningful pattern can be identified. For example, of the 11 studies that specifically mentioned education as a variable, 5 found that it was not significantly associated with treatment approval or acceptance (Fried et al. 2006, Lim et al. 2009, Loomis et al. 2002, Shindler and Toman 2003, Toman et al. 2011). Two other studies found education significantly associated at some level with treatment approval: Absher and Vaske (2006) found a composite demographic variable was associated with approval of prescribed burning and thinning; and Shindler et al. (2011) found that education was associated with prescribed fire acceptance for rural, but not urban, residents. Of the remaining studies, significant relationships with education were found for concern about certain treatment outcomes but not with approval (Lim et al. 2009), desire to be informed about restoration activities (Ostergren et al. 2006), change of attitude after receiving information (Toman and Shindler 2006), views on cutting trees and aesthetics (Weible et al. 2005), and trust levels (Winter and Cvetkovich 2008). One possible reason 
for this variation may be that, when significant, sociodemographic variables may simply reflect other more important dynamics within the study. For example, although McCaffrey et al. (2008) did find several significant demographic relationships, they also found that the variables were strongly correlated with group membership, which the authors determined was a more consistently explanatory factor than the demographic variables.

The two socio-demographic variables where some pattern can be identified are gender and type of residency (permanent or part-time). In both cases, however, it is important to note that the majority of studies either do not report on the variables or find no significant relationship with fire-related attitudes and behaviors. Gender differences have been found in relation to information and knowledge change (Toman and Shindler 2006), but are most commonly found in relation to risk response: studies have found that women have higher risk perception and concern levels and lower support for more controversial practices such as prescribed fire and herbicides (Jarrett et al. 2009; Lim et al. 2009; McCaffrey 2008a, b; Ryan and Wamsley 2008; Shindler et al. 2009, 2011). Worth noting is that Winter and Cvetkovich (2008) found a number of significant differences for gender, but also found that gender response differed by racial group. For instance, white females expressed more concern about fire than did white males, while African American females expressed less concern than African American males.

In terms of differences between part-time/seasonal and full-time/permanent residents, Toman et al. (2011) initially found that permanent residency was positively correlated with acceptance of prescribed fire and thinning but in subsequent regression analysis found no relationship. Vogt et al. (2003) found that the main significant differences between permanent and seasonal residents were in experiences with wildfire and that there was little difference between the two groups in approval of fuels treatments and defensible space. Fischer (2011) found that private forest owners whose primary residence was on the parcel were more likely to undertake fuels treatments on their land, and that distance of primary residence from the parcel was negatively associated with such actions. In relation to defensible space, Collins and Bolin (2009) found that part-time residents were less inclined to mitigate while full-time residents were more likely to take collective action in their neighborhoods. Similarly, Bright and Burtz (2006) found that full-time residents were more likely to undertake certain defensible space activities and that social norms (i.e., influence of other people's opinions) were significantly associated with permanent residents' landscaping activities. Seasonal residents in turn placed greater emphasis on lack of time as a barrier and their perceived behavior control (i.e., ability to overcome barriers such as limited time) was significantly associated with their undertaking clearing activities. In another study, part-time residents routinely brought up time as a key barrier, but the authors found that interactions with full-time neighbors helped to engage part-time residents in mitigation actions and that a comparable or higher percentage of part-time residents had undertaken the simpler vegetative actions of pruning trees and clearing underbrush (Brenkert-Smith 2010). This last pair of findings suggests that time may be a key variable shaping seasonal residents' actions and that neighborhood norms can also be an important factor, particularly for permanent residents.

Finally, a study by Absher and Vaske (2006) suggests why significant findings related to socio-demographic factors are so limited. While they did find that a composite variable of four demographic measures was significantly related to approval of prescribed fire and thinning and a second composite variable of residential factors was significantly related to likelihood of taking defensible space actions, each variable explained less than 7 percent of response variance. On the other hand, a psychological composite variable (familiarity, 
effectiveness, aesthetics) explained 27-44 percent of response variance for each activity, indicating that these latter factors are much more important in determining approval.

\section{Differences Between Groups}

The few studies that have examined ethnicity or race have found a number of differences between groups (Bowker et al. 2008, Carroll et al. 2004, Jarrett et al. 2009, Lim et al. 2009, Loomis et al. 2002, Winter and Cvetkovich 2008). In the Southeast, Jarrett et al. (2009) found that Caucasians were more likely than non-Caucasians to perceive the wildfire threat, have experienced wildfire, use wildfire program information, and construct fire lines. Caucasians also were less interested in workshops and government or technical assistance than other races studied. A national survey found a number of significant differences between three racial/ethnic groups: African Americans and Hispanics were less likely than Caucasians to support prescribed fire and were more concerned about smoke, harm to wildlife, and aesthetics (Lim et al. 2009). In a separate analysis on the same data, Bowker et al. (2008) found a number of significant differences among the three groups on acceptance of pre- and post-fire management actions and views of personal responsibility for mitigating risk. In four southwest states, Winter and Cvetkovich (2008) also found significant differences in concern about wildfire, wildfire knowledge, and agency trust among five different racial/ethnic groups: Native Americans, Hispanics, non-Hispanic whites, African Americans, and Asian Americans.

Several studies suggest that the key factor shaping differences in views of fire management may be a more intangible factor such as worldviews (Bright et al. 2007b, Burns and Cheng 2007, Liou et al. 2007, Mendez et al. 2003), group membership (Carroll et al. 2004, Collins and Bolin 2009, Findley et al. 2001, McCaffrey et al. 2008, Weible et al. 2005,
Weisshaupt et al. 2007), or preferred use of public lands (Kwon et al. 2008, Ryan 2010, Shindler et al. 2011, Vogt et al. 2007). For example, McCaffrey et al. (2008) found that the primary explanatory factor for differences in level of acceptability of a treatment and treatment preferences was stakeholder group membership (e.g., entomologists, environmentalists, educational). In Arizona, amenity migrants were more likely than working-class locals to discuss conflicting environmental values when considering defensible space (Collins and Bolin 2009). In a Colorado survey, Bright et al. (2007b) identified two distinct groups, individualist and non-individualist, based on responses to four belief dimensions: trust in land management agencies, freedom to build homes in the WUI, and government's and homeowners' responsibility to protect homes from forest fires. The individualist group had high levels of agreement for the importance of personal freedom and homeowner responsibility, slightly agreed that they trusted land management agencies, and disagreed that it was the government's responsibility to protect homes. The non-individualist group disagreed with the idea of personal freedom and had relatively high levels of trust in land management agencies, a neutral response on governmental responsibility, and agreement, although at a lower level, that homeowners were responsible for protecting homes from wildfire.

\section{Summary}

While there is always a range of public response to different aspects of fire management, research suggests that, except for ethnicity and race, these differences are difficult to attribute to easily measurable or mappable variables, such as demographics and geography. Instead, more complex, often identitybased, and harder-to-measure factors, such as worldview and group membership, appear more likely to explain variation in how individuals respond to fire management issues. 


\section{CONCLUSIONS}

Although the answers to some questions have more evidence than others, overall the findings provide a fairly clear indication that public response to a variety of fire management issues is more positive than is often assumed and much more complex and sophisticated than the common truism "Smokey has taught the public to see all fire as bad" allows for. Indeed, the majority of the public, particularly in areas with high fire risk, has a fairly sophisticated understanding of fire ecology and behavior. The public's concern for improving forest health and reducing the risk of wildfire underlies strong support for at least some level of prescribed burning and mechanized thinning. Support for active management is also shaped by recognition of the shared risk across land ownerships and an associated sense of shared responsibility whereby land owners, whether public or private, are expected to mitigate the fire risk on their land.

No single factor leads to approval of a fuels treatment; rather, a variety of issues are taken into account in informal tradeoff assessments that determine approval. (See Figure 1 for a basic conceptual model of how these factors appear to interact.) Knowledge of a practice, particularly its ecological benefits, is

\section{Fire/Fuels Management Public Acceptance Model (Thinning, Prescribed Fire)}

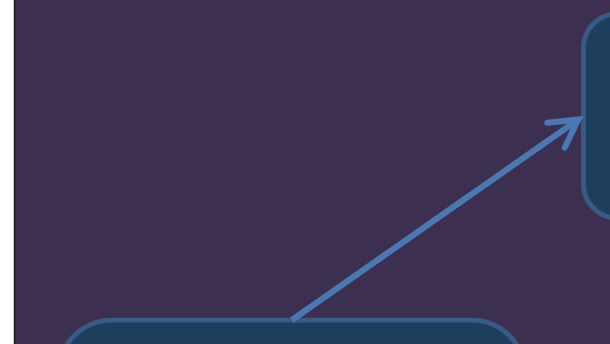

Communication Process Interactivity Content

\section{Trust} Credibility Competence

Perceived Level of Fire Risk

Concerns Prescribed fire (escape, smoke) Aesthetics, other values (+, -) Shared risk (+, -)

Understanding Ecological Benefit Risk reduction Cost-effectiveness Health and safety
Acceptance

of Fire/Fuels Management $\underline{\text { Underline }}=$ Key Factor

Dotted line $=$ more contextual dynamic
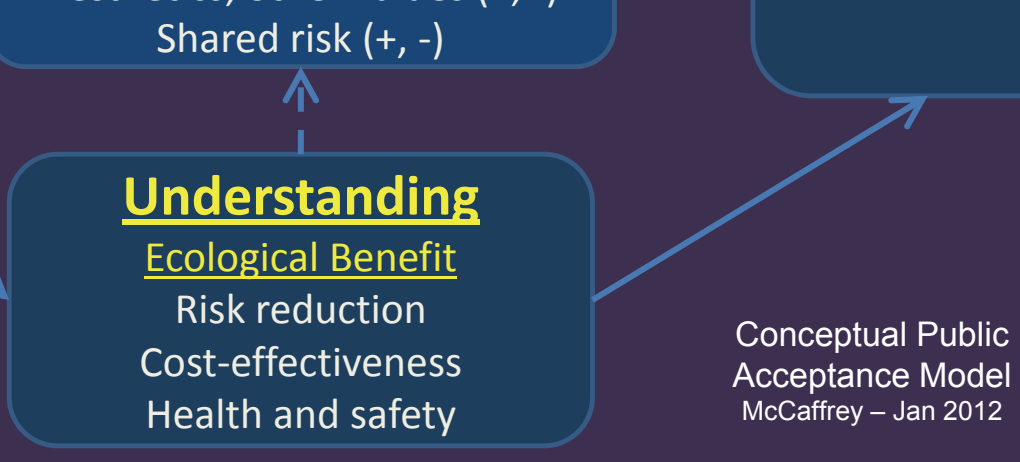

Figure 1.- Conceptual model of factors that influence public acceptance of fuels treatments. 
associated with acceptance. However, as Brunson and Shindler (2004) noted, higher public acceptance cannot be developed simply by increasing knowledge, as other factors also come into play. Key among these is the level of trust in those implementing a practice. Although evidence is limited, concerns about health and safety and cost-effectiveness appear to be underlying considerations in judging appropriateness.

Many factors interact to influence each individual differently. For example, smoke appears to be particularly important for those households with respiratory issues and less important for the remainder of the population. In addition, different individuals can respond differently to the same consideration, such as treatment effect on wildlife or aesthetics, depending on their values. Finally, although socio-demographic factors and large-scale geographic differences if significant would simplify prediction of likely response in a specific community or region, neither set of factors appears to explain differences in beliefs or acceptance. Rather, differences in response appear to be due more to specific local contextual distinctions or more intangible elements such as individual worldview or stakeholder group membership.

How the public accesses information on fire and fire management is a complex process where no single source is always more effective than another: different sources will be used in different geographic areas and by different individuals at different points in time. While government agencies are a preferred information source under most circumstances, individuals will turn to multiple sources and assess which one they think is most useful and trustworthy. The most consistent finding is that interactive information sources are both generally preferred and more effective. Such interactive communication with government sources also helps build trust and improves relationships.
Together these findings provide quite a bit of good news. Overall, the public has a reasonably sophisticated understanding of fire, is supportive of active management to reduce fire risk and improve forest health, and takes responsibility for mitigating the risk on its property. At the same time there is a bit of bad news - no single piece of information or best information source shapes acceptance of active fire management or compliance with mitigation recommendations. Taken together, however, this body of research suggests that interactivity is a key feature of information dissemination. The consistent, positive impact of interaction on trust and acceptance of firerelated information argues for emphasizing interaction in outreach efforts at the local level. Interactive outreach can achieve multiple objectives by increasing the knowledge base and building agency-community trust, both of which will be critical to mitigating future fire risk and improving landscape health.

Finally, as was evident throughout this report, several topics cannot be answered definitively due to lack of research attention, suggesting areas where future research studies could contribute valuable information for fire management. In particular, more work is needed to understand social response during and after fires and whether and how that response differs from and is influenced by response before a fire. For example, what distinctions, if any, do members of the public make in how they see protection responsibilities before versus during a fire? While a picture is developing of a public that is more knowledgeable and supportive of fire management endeavors than is often thought to be the case, better understanding such intricacies throughout the entire fire management cycle could help identify how to build on that support and design programs and policies that can cost-effectively restore fire-adapted ecosystems while reducing negative outcomes of future fires. 


\section{ACKNOWLEDGMENTS}

The authors thank Ryan Gordon for preliminary design of this publication.

\section{LITERATURE CITED}

Absher, J.D.; Vaske, J.J. 2006. An analysis of homeowner and agency wildland fire mitigation strategies. In: Peden, J.G.; Schuster, R.M., eds. Proceedings of the 2005 northeastern recreation research symposium. Gen. Tech. Rep. NE341. Newtown Square, PA: U.S. Department of Agriculture, Forest Service, Northeastern Research Station: 231-236.

Absher, J.D.; Vaske, J.J. 2011. The role of trust in residents' fire wise actions. International Journal of Wildland Fire. 20(2): 318-325.

Absher, J.D.; Vaske, J.J.; Shelby, L.B. 2009.

Residents' responses to wildland fire programs: a review of cognitive and behavioral studies. Gen. Tech. Rep. PSW-223. Riverside, CA: U.S. Department of Agriculture, Forest Service, Pacific Southwest Research Station. 31 p.

Agrawal, S.; Monroe, M.C. 2006. Using and improving social capital to increase community preparedness for wildfire. In: McCaffrey, S., ed. The public and wildland fire management: social science findings for managers. Gen. Tech. Rep. NRS-1. Newtown Square, PA: U.S. Department of Agriculture, Forest Service, Northern Research Station: 163-167.
Arvai, J.; Gregory, R.; Ohlson, D.; Blackwell, B.; Gray, R. 2006. Letdowns, wake-up calls, and constructed preferences: people's responses to fuel and wildfire risks. Journal of Forestry. 104(4): 173-181.

Bell, T.; Oliveras, I. 2006. Perceptions of prescribed burning in a local forest community in Victoria, Australia. Environmental Management. 38(5): 867-878.

Blanchard, B.; Ryan, R. 2007. Managing the wildland-urban interface in the Northeast: perceptions of fire risk and hazard reduction strategies. Northern Journal of Applied Forestry. 24(3): 203-208.

Bowker, J.M.; Lim, S.H.; Cordell, H.K.; Green, G.T.; Rideout-Hanzak, S.; Johnson, C.Y. 2008. Wildland fire, risk, and recovery: results of a national survey with regional and racial perspectives. Journal of Forestry. 106(5): 268-276.

Brenkert-Smith, H. 2010. Building bridges to fight fire: the role of informal social interactions in six Colorado wildland-urban interface communities. International Journal of Wildland Fire. 19(6): 689-697.

Brenkert-Smith, H. 2011. Homeowners' perspectives on parcel approach to wildland fire mitigation: the role of community context in two Colorado communities. Journal of Forestry. 109(4): 193-200.

Brenkert-Smith, H.; Champ, P.A.; Flores, N. 2006. Insights into wildfire mitigation decisions among wildland-urban interface residents. Society and Natural Resources. 19(8): 759-768.

Bright, A.D.; Burtz, R.T. 2006. Firewise activities of full-time versus seasonal residents in the wildland-urban interface. Journal of Forestry. 104(6): 307-315. 
Bright, A.D.; Don Carlos, A.W.; Vaske, J.J.; Absher, J.D. 2007a. Source credibility and the effectiveness of firewise information. In: Burns, R.; Robinson, K., eds. Proceedings of the 2006 northeastern recreation research symposium. Gen. Tech. Rep. NRS-P-14. Newtown Square, PA: U.S. Department of Agriculture, Forest Service, Northern Research Station: 551-556.

Bright, A.D.; Newman, P. 2006. How forest context influences the acceptability of prescribed burning and mechanical thinning. In: McCaffrey, S., ed. The public and wildland fire management: social science findings for managers. Gen. Tech. Rep. NRS-1. Newtown Square, PA: U.S. Department of Agriculture, Forest Service, Northern Research Station: 47-52.

Bright, A.D.; Newman, P.; Carroll, J. 2007b. Context, beliefs, and attitudes toward wildland fire management: an examination of residents of the wildland-urban interface. Human Ecology Review. 14(2): 212-222.

Brunson, M.W.; Evans, J. 2005. Badly burned? Effects of an escaped prescribed burn on social acceptability of wildland fuels treatments. Journal of Forestry. 103(3): 134-138.

Brunson, M.W.; Shindler, B.A. 2004. Geographic variation in social acceptability of wildland fuels management in the Western United States. Society and Natural Resources. 17(8): 661-678.

Burns, M.; Cheng, A.S. 2007. Framing the need for active management for wildfire mitigation and forest restoration. Society and Natural Resources. 20(3): 245-259.

Carroll, M.S.; Cohn, P.J.; Blatner, K.A. 2004. Private and tribal forest landowners and fire risk: a twocounty case study in Washington State. Canadian Journal of Forest Research. 34(10): 2148-2158.
Carroll, M.S.; Cohn, P.J.; Seesholtz, D.N.; Higgins, L.L. 2005. Fire as a galvanizing and fragmenting influence in communities: the case of the RodeoChediski Fire. Society and Natural Resources. 18(4): 301-320.

Cohn, P.J.; Williams, D.R.; Carroll, M.S. 2008. Wildland-urban interface residents' views on risk and attribution. In: Martin, W.; Raish, C.; Kents, B., eds. Wildlfire risk: human perceptions and management implications. Washington, DC: Resources for the Future: 23-43.

Collins, T.W. 2009. Influences on wildfire hazard exposure in Arizona's High Country. Society and Natural Resources. 22(3): 211-229.

Collins, T.W.; Bolin, B. 2009. Situating hazard vulnerability: people's negotiations with wildfire environments in the U.S. Southwest. Environmental Management. 44(3): 441-455.

Daniel, T.C. 2006. Public preferences for future conditions in disturbed and undisturbed northern forest sites. In: McCaffrey, S., ed. The public and wildland fire management: social science findings for managers. Gen. Tech. Rep. NRS-1. Newtown Square, PA: U.S. Department of Agriculture, Forest Service, Northern Research Station: 53-61.

Findley, A.J.; Carroll, M.S.; Blatner, K.A. 2001. Social complexity and the management of smalldiameter stands. Journal of Forestry. 99(12): $18-27$

Fischer, A.P. 2011. Reducing hazardous fuels on nonindustrial private forests: factors influencing landowner decisions. Journal of Forestry. July/ August: 260-266.

Flint, C.G. 2006. Community perspectives on spruce beetle impacts on the Kenai Peninsula, Alaska. Forest Ecology and Management. 227(3): 207-218. 
Flint, C.G. 2007. Changing forest disturbance regimes and risk perceptions in Homer, Alaska. Risk Analysis. 27(6): 1597-1608.

Fried, J.S.; Gatziolis, D.; Gilless, J.K.; Vogt, C.; Winter, G. 2006*. Changing the beliefs and building trust at the wildland/urban interface. Fire Management Today. 66(3): 51-54.

Gordon, J.S.; Stedman, R.C.; Luloff, A.E. 2010. West Virginia wildland fire as latent social discontent. Society and Natural Resources. 23(12): 1230-1243.

Gunderson, K. 2006. Understanding place meanings for wilderness: personal and community values at risk. International Journal of Wilderness. 12(1): 27-31.

Gunderson, K.; Watson, A. 2007. Understanding place meanings on the Bitterroot National Forest, Montana. Society and Natural Resources. 20(8): 705-721.

Jacobson, S.K.; Monroe, M.C.; Marynowski, S. 2001. Fire at the wildland interface: the influence of experience and mass media on public knowledge, attitudes, and behavioral intentions. Wildlife Society Bulletin. 29(3): 929-937.

Jarrett, A.; Gan, J.; Johnson, C.; Munn, I.A. 2009. Landowner awareness and adoption of wildfire programs in the Southern United States. Journal of Forestry. 107(3): 113-118.

Kaval, P. 2007*. The link between perceived and actual wildfire danger: an economic and spatial analysis study in Colorado (USA). Working Paper in Economics 07/13. Hamilton, New Zealand:

University of Waikato. $15 \mathrm{p}$.
Kaval, P.; Loomis, J. 2008. Using GIS to test the relationship between homeowner willingness to pay to reduce wildfire and landscape characteristics. In: Gonzalez-Caban, A., ed. Proceedings of the second international symposium on fire economics, planning, and policy: a global view. Gen. Tech. Rep. PSW-208. Albany, CA: U.S. Department of Agriculture, Forest Service, Pacific Southwest Research Station: 231-240.

Kaval, P.; Loomis, J.; Theobald, D. 2006*.

Investigating the relationship between stakeholder opinion about wildfire management and landscape context using GIS. Working Paper in Economics 06/13. Hamilton, New Zealand: University of Waikato. $23 \mathrm{p}$.

Kent, B.; Gebert, K.; McCaffrey, S.; Martin, W.; Calkin, D.; Schuster, E.; Martin, I.; Bender, H.W.; Alward, G.; Kumagai, Y.; Cohn, P.J.; Carroll, M.; Williams, D.; Ekarius, C. 2003. Social and economic issues of the Hayman Fire. In: Graham, R.T., ed. Hayman Fire case study. Gen Tech. Rep. RMRS-114. Ogden, UT: U.S. Department of Agriculture, Forest Service, Rocky Mountain Research Station: 315-395.

Kneeshaw, K.; Vaske, J.J.; Bright, A.D.; Absher, J.D. 2004a. Acceptability norms toward fire management in three national forests. Environment and Behavior. 36(4): 592-612.

Kneeshaw, K.; Vaske, J.J.; Bright, A.D.; Absher, J.D. 2004b. Situational influences of acceptable wildland fire management actions. Society and Natural Resources. 17(6): 477-489.

Knotek, K.; Watson, A.E.; Borrie, W.T.; Whitmore, J.G.; Turner, D. 2008. Recreation visitor attitudes towards management-ignited prescribed fires in the Bob Marshall Wilderness Complex, Montana. Journal of Leisure Research. 40(4): 608-618. 
Kumagai, Y.; Bliss, J.C.; Daniels, S.E.; Carroll, M.S. 2004. Research on causal attribution of wildfire: an exploratory multiple-methods approach. Society and Natural Resources. 17(2): 113-127.

Kwon, J.; Vogt, C.; Winter, G.; McCaffrey, S. 2008. Forest fuels treatments for wildlife management: Do local recreation users agree? In: LeBlanc, C.; Vogt, C., eds. Proceedings of the 2007 northeastern recreation research symposium. Gen. Tech. Rep. NRS-P-23. Newtown Square, PA: U.S. Department of Agriculture, Forest Service, Northern Research Station: 132-137.

Lim, S.H.; Bowker, J.M.; Johnson, C.Y.; Cordell, H.K. 2009. Perspectives on prescribed fire in the South: Does ethnicity matter? Southern Journal of Applied Forestry. 33(1): 17-24.

Liou, G.; Vogt, C.; Winter, G.; McCaffrey, S. 2008. Residents' values and fuels management approaches. In: LeBlanc, C.; Vogt, C., eds. Proceedings of the 2007 northeastern recreation research symposium. Gen. Tech. Rep. NRS-P23. Newtown Square, PA: U.S. Department of Agriculture, Forest Service, Northern Research Station: 77-83.

Loomis, J.B.; Bair, L.S.; Gonzalez-Caban, A. 2001. Prescribed fire and public support: knowledge gained, attitudes changed in Florida. Journal of Forestry. 99(11): 18-22.

Loomis, J.B.; Bair, L.S.; Gonzalez-Caban, A. 2002. Language-related differences in a contingent valuation study: English versus Spanish. American Journal of Agricultural Economics. 84(4): 1091-1102.

Martin, I.M.; Bender, H.; Raish, C. 2007. What motivates individuals to protect themselves from risks: the case of wildland fires. Risk Analysis. 27(4): 887-900.
McCaffrey, S. 2004. Fighting fire with education: What is the best way to reach out to homeowners? Journal of Forestry. 102(5): 12-19.

McCaffrey, S. 2006. Prescribed fire: What influences public approval? In: Dickinson, M.B., ed. Fire in eastern oak forests: delivering science to land managers. Gen. Tech. Rep. NRSP-1. Newtown Square, PA: U.S. Department of Agriculture, Forest Service, Northern Research Station: 192-198.

McCaffrey, S. 2008a. The homeowner view of thinning methods for fire hazard reduction: more positive than many think. In: Narog, M.G., tech coord. Proceedings of the 2002 fire conference: managing fire and fuels in the remaining wildlands and open spaces of the Southwestern United States. Gen. Tech. Rep. PSW-GTR-189. Albany, CA: U.S. Department of Agriculture, Forest Service, Pacific Southwest Research Station: 15-22.

McCaffrey, S. 2008b. Understanding public perspectives of wildfire risk. In: Martin, W.E.; Raish, C.; Kent, B., eds. Wildfire risk, human perceptions and management implications. Washington, DC: Resources for the Future: 11-22.

McCaffrey, S.; Moghaddas, J.J.; Stephens, S.L. 2008. Different interest group views of fuel treatments: survey results from fire and fire surrogate treatments in Sierran mixed conifer forest, California, USA. International Journal of Wildland Fire. 17(2): 224-233.

McCaffrey, S.; Stidham, M.; Toman, E.; Shindler, B. 2011. Outreach programs, peer pressure, and common sense: What motivates homeowners to mitigate fire risk? Environmental Management. 48(3): 475-488. 
McCaffrey, S.; Winter, G. 2011. Understanding homeowner preparation and intended actions when threatened by a wildfire. In: McCaffrey, S.; LeBlanc, C., eds. Proceedings of the second human dimensions of wildland fire conference. Gen. Tech. Rep. NRS-P-84. Newtown Square, PA: U.S. Department of Agriculture, Forest Service, Northern Research Station: 88-95. [Online only].

McFarlane, B.L.; Angell, A.C.; McGee, T.K. 2007*. Public perceptions of wildland fire management in the Foothills Model Forest: a summary of findings. Unpublished report.

McGee, T.K. 2011. Public engagement in neighbourhood level wildfire mitigation and preparedness: case studies from Canada, the US and Australia. Journal of Environmental Management. 92: 2524-2532.

Mendez, S.R.; Carroll, M.S.; Blatner, K.A.; Findley, A.J.; Walker, G.B.; Daniels, S.E. 2003. Smoke on the hill: a comparative study of wildfire and two communities. Western Journal of Applied Forestry. 18(1): 60-70.

Monroe, M.C.; Nelson, K.C. 2004. The value of assessing public perceptions: wildland fire and defensible space. Applied Environmental Education and Communication. 3(2): 109-117.

Monroe, M.C.; Nelson, K.C.; Payton, M. 2006. Communicating with homeowners in the interface about defensible space. In: McCaffrey, S., ed. The public and wildland fire management: social science findings for managers. Gen. Tech. Rep. NRS-1. Newtown Square, PA: U.S. Department of Agriculture, Forest Service, Northern Research Station: 99-109.

Nelson, K.C.; Monroe, M.C.; Johnson, J.F.; Bowers, A. 2004. Living with fire: homeowner assessment of landscape values and defensible space in Minnesota and Florida, USA. International Journal of Wildland Fire. 13(4): 413-425.
Olsen, C.S.; Shindler, B.A. 2010. Trust, acceptance, and citizen-agency interactions after large fires: influences on planning processes. International Journal of Wildland Fire. 19(1): 137-147.

Ostergren, D.M.; Lowe, K.A.; Abrams, J.B.; Ruther, E.J. 2006. Public perceptions of forest management in North Central Arizona: the paradox of demanding more involvement but allowing limits to legal action. Journal of Forestry. 104(7): 375-382.

Parkinson, T.M.; Force, J.E.; Smith, J.K. 2003. Handson learning: its effectiveness in teaching the public about wildland fire. Journal of Forestry. 101(7): 21-26.

Paveglio, T.; Carroll, M.S.; Absher, J.D.; Norton, T. 2009. Just blowing smoke? Residents' social construction of communication about wildfire. Environmental Communication. 3(1): 76-94.

Paveglio, T.B.; Carroll, M.S.; Absher, J.; Robinson, E. 2011. Symbolic meaning of wildland fire: a study of residents in the U.S. Inland Northwest. Society and Natural Resources. 24(1): 18-33.

Rasmussen, K.; Hibbard, M.; Lynn, K. 2007. Wildland fire management as conservationbased development: an opportunity for reservation communities? Society and Natural Resources. 20(6): 497-510.

Ryan, R.L. 2010. Local residents' preferences and attitudes toward creating defensible space against wildfire in the Northeast Pine Barrens. Landscape Journal. 29: 2-10.

Ryan, R.L.; Hamin, E. 2008. Wildfires, communities, and agencies: stakeholders' perceptions of postfire forest restoration and rehabilitation. Journal of Forestry. 106(7): 370-379. 
Ryan, R.L.; Wamsley, M.B. 2008. Public perceptions of wildfire risk and forest management in the Central Pine Barrens of Long Island (USA). The Australasian Journal of Disaster. 2008-2. Available at http://www.massey.ac.nz/ trauma/issues/20082/ryan.htm. (Accessed 13 June 2011).

Ryan, R.L.; Wamsley, M.B.; Blanchard, B.P. 2006. Perceptions of wildfire threat and mitigation measures by residents of fire-prone communities in the Northeast: survey results and wildland fire management implications. In: McCaffrey, S., ed. The public and wildland fire management: social science findings for managers. Gen. Tech. Rep. NRS-1. Newtown Square, PA: U.S. Department of Agriculture, Forest Service, Northern Research Station: 11-17.

Schulte, S.; Miller, K.A. 2010. Wildfire risk and climate change: the influence on homeowner mitigation behavior in the wildland-urban interface. Society and Natural Resources. 23(5): 417-435.

Shindler, B.A.; Gordon, R.; Brunson, M.W.; Olsen, C. 2011. Public perspectives of sagebrush ecosystem management in the Great Basin. Rangeland Ecology \& Management. 64(4): 335-343.

Shindler, B.A.; Toman, E. 2003. Fuel reduction strategies in forest communities: a longitudinal analysis of public support. Journal of Forestry. 101(6): 8-15.

Shindler, B.A.; Toman, E.; McCaffrey, S.M. 2009. Public perspectives of fire, fuels and the Forest Service in the Great Lakes Region: a survey of citizen-agency communication and trust. International Journal of Wildland Fire. 18(2): 157-164.
Shiralipour, H.J.; Monroe, M.C.; Nelson, K.C.; Payton, M. 2006. Working with neighborhood organizations to promote wildfire preparedness. In: McCaffrey, S., ed. The public and wildland fire management: social science findings for managers. Gen. Tech. Rep. NRS-1. Newtown Square, PA: U.S. Department of Agriculture, Forest Service, Northern Research Station: 151-162.

Steelman, T.; McCaffrey, S. 2010*. Agencycommunity interactions during wildfires. Joint Fire Science Program project \#08-1-4-01. Unpublished raw data.

Taylor, J.G.; Gillette, S.C.; Hodgson, R.W.; Downing, J.L.; Burns, M.R.; Chavez, D.J.; Hogan, J.T. 2007. Informing the network: improving communication with interface communities during wildfire. Human Ecology Review. 14(2): 198-211.

Thapa, B.; Holland, S.M.; Absher, J.D. 2004. The relationship between wildfires and tourist behaviors in Florida: an exploratory study. In: Tierney, P.T.; Chavez, D.J., eds. Proceedings of the 4th social aspects and recreation research symposium; February 4-6, 2004; San Francisco, CA. San Francisco, CA: San Francisco State University: 154-161.

Toman, E.; Shindler, B. 2006. Communicating the wildland fire message: influences on knowledge and attitude change in two case studies. In: Andrews, P.L.; Butler, B.W., eds. Fuels management - how to measure for success: conference proceedings. Proceedings RMRS-P-41. Fort Collins, CO: U.S. Department of Agriculture, Forest Service, Rocky Mountain Research Station: 715-728. 
Toman, E.L.; Shindler, B.; Absher, J.; McCaffrey, S. 2008. Postfire communications: the influence of site visits on local support. Journal of Forestry. 106(1): 25-30.

Toman, E.; Shindler, B.; Brunson, M. 2006. Fire and fuel management communication strategies: citizen evaluations of agency outreach activities. Society and Natural Resources. 19(4): 321-336.

Toman, E.; Shindler, B.; Reed, M. 2004. Prescribed fire: the influence of site visits on citizen attitudes. The Journal of Environmental Education. 35(3): 13-17.

Toman, E.; Stidham, M.; Shindler, B.; McCaffrey, S. 2011. Reducing fuels in the wildland-urban interface: community perceptions of agency fuels treatments. International Journal of Wildland Fire. 20(3): 340-349.

Vaske, J.J.; Absher, J.D.; Bright, A.D. 2007. Salient value similarity, social trust and attitudes toward wildland fire management strategies. Human Ecology Review. 14(2): 223-232.

Vining, J.; Merrick, M.S. 2008. The influence of proximity to a National Forest on emotions and fire-management decisions. Environmental Management. 41(2): 155-167.

Vogt, C. 2003. Seasonal and permanent home owners' past experiences and approval of fuels reduction. In: Jakes, P., ed. Homeowners, communities, and wildfire: science findings from the National Fire Plan; proceedings of the ninth international symposium on society and resource management; June 2-5, 2002; Bloomington, IN. Gen. Tech. Rep. NC-231. St. Paul, MN: U.S. Department of Agriculture, Forest Service, North Central Research Station: 63-73.
Vogt, C.A.; Winter, G.; Fried, J.S. 2005. Predicting homeowners' approval of fuel management at the wildland-urban interface using the theory of reasoned action. Society and Natural Resources. 18(4): 337-354.

Vogt, C.; Winter, G.; McCaffrey, S. 2007. Community views of fuels management: Are National Forest local recreation users more supportive? In: Burns, R.; Robinson, K. Proceedings of the 2006 northeastern recreation research symposium. Gen. Tech. Rep. NRS-P-14. Newtown Square, PA: U.S. Department of Agriculture, Forest Service, Northern Research Station: 546-550.

Vogt, C.; Winter, G.; McCaffrey, S. 2009*. Individual response to voluntary and involuntary incentives to mitigate fire hazard: what works and what doesn't? Final Report to the Joint Fire Science Program. JFSP 05-3-2-05. 22 p.

Walker, S.H.; Rideout, D.B.; Loomis, J.B.; Reich, R. 2007. Comparing the value of fuel treatment options in northern Colorado's urban and wildland-urban interface areas. Forest Policy and Economics. 9(6): 694-703.

Weible, C.; Sabatier, P.; Nechodom, M. 2005. No sparks fly: Policy participants agree on thinning trees in the Lake Tahoe Basin. Journal of Forestry. 103(1): 5-9.

Weisshaupt, B.R.; Carroll, M.S.; Blatner, K.A.; Robinson, W.D.; Jakes, P.J. 2005. Acceptability of smoke from prescribed forest burning in the Northern Inland West: a focus group approach. Journal of Forestry. 103(4): 189-193.

Weisshaupt, B.R.; Jakes, P.J.; Carroll, M.S.; Blatner, K.A. 2007. Northern Inland West land/homeowner perceptions of fire risk and responsibility in the wildland-urban interface. Human Ecology Review. 14(2): 177-187. 
Winter, P.L.; Cvetkovich, G.T. 2008. Diversity of southwesterners' views of Forest Service fire management. In: Martin, W.; Raish, C.; Kents, B., eds. Wildfire risk: human perceptions and management implications. Washington, DC: Resources for the Future: 156-170.

Winter, P.L.; Cvetkovich, G.T. 2010. Shared values and trust: the experience of community residents in a fire-prone ecosystem. In: Pye, J.M.; Raushcer, H.M.; Sands, Y.; Lee, D.C.; Beatty, J.S., eds.

Advances in threat assessment and their application to forest and rangeland management. Gen. Tech. Rep. PNW-802. Portland, OR: U.S. Department of Agriculture, Forest Service, Pacific Northwest Research Station: 409-418.

Winter, G.; McCaffrey, S.; Vogt, C.A. 2009. The role of community policies in defensible space compliance. Forest Policy and Economics. 11(8): 570-578.
Winter, G.J.; Vogt, C.; Fried, J.S. 2002. Fuel treatments at the wildland-urban interface: common concerns in diverse regions. Journal of Forestry. 100(1): 15-21.

Winter, G.; Vogt, C.; McCaffrey, S. 2004. Examining social trust in fuels management strategies. Journal of Forestry. 102(6): 8-15.

Winter, G.; Vogt, C.; McCaffrey, S. 2006. Residents warming up to fuels management: homeowners' acceptance of wildfire and fuels management in the wildland-urban interface. In: McCaffrey, S., ed. The public and wildland fire management: social science findings for managers. Gen. Tech. Rep. NRS -1. Newtown Square, PA: U.S. Department of Agriculture, Forest Service, Northern Research Station: 19-32. 


\section{APPENDIX I}

\begin{tabular}{|c|c|c|c|c|}
\hline Study citation & Study site(s) & Method & General topics & Questions \\
\hline Absher et al. 2009 & Multiple & $\begin{array}{l}\text { Summary of } \\
\text { three studies }\end{array}$ & $\begin{array}{l}\text { Defensible space, } \\
\text { Information }\end{array}$ & Responsibility, Cost \\
\hline $\begin{array}{l}\text { Absher and Vaske } 2011 \text {, } \\
\text { Absher and Vaske 2006, } \\
\text { Vaske } 2007\end{array}$ & $\begin{array}{l}\text { Colorado } \\
\text { (Front Range) }\end{array}$ & Survey & $\begin{array}{l}\text { Defensible space, } \\
\text { Information }\end{array}$ & $\begin{array}{l}\text { Information, } \\
\text { Fuels reduction, } \\
\text { Responsibility, Cost, } \\
\text { Differences }\end{array}$ \\
\hline Arvai et al. 2006 & British Columbia & $\begin{array}{l}\text { Workshop, } \\
\text { Survey }\end{array}$ & Fire management & Cost \\
\hline $\begin{array}{l}\text { Bowker et al. } 2008, \\
\text { Lim et al. } 2009 \text { (southern states) }\end{array}$ & National & Survey & $\begin{array}{l}\text { Fire management } \\
\text { module of } \\
\text { Recreation and } \\
\text { Environment Survey }\end{array}$ & $\begin{array}{l}\text { Fuels reduction, } \\
\text { Smoke, Responsibility, } \\
\text { Cost, Differences }\end{array}$ \\
\hline $\begin{array}{l}\text { Brenkert-Smith et al. 2006, } \\
\text { Brenkert-Smith 2010, } \\
\text { Brenkert-Smith 2011 }\end{array}$ & $\begin{array}{l}\text { Colorado (Front } \\
\text { Range) }\end{array}$ & Interviews & Defensible space & $\begin{array}{l}\text { Knowledge, } \\
\text { Information, } \\
\text { Responsibility, } \\
\text { Differences }\end{array}$ \\
\hline Bright and Burtz 2006 & Minnesota & Survey & Defensible space & Differences \\
\hline $\begin{array}{l}\text { Bright and Newman } 2006 \text {, } \\
\text { Bright et al. 2007b (CO only) }\end{array}$ & $\begin{array}{l}\text { Colorado } \\
\text { (Front Range), } \\
\text { southern Illinois, } \\
\text { Chicago }\end{array}$ & Survey & $\begin{array}{l}\text { Fuels management, } \\
\text { Defensible space }\end{array}$ & $\begin{array}{l}\text { Information, } \\
\text { Fuels reduction, } \\
\text { Differences }\end{array}$ \\
\hline Bright et al. 2007a & $\begin{array}{l}\text { Colorado } \\
\text { (Front Range) }\end{array}$ & Survey & Information & Information \\
\hline Brunson and Evans 2005 & Utah & Survey & Fire management & $\begin{array}{l}\text { Smoke, } \\
\text { Health and safety, } \\
\text { Cost, Differences }\end{array}$ \\
\hline $\begin{array}{l}\text { Brunson and Shindler 2004, } \\
\text { Toman et al. } 2006\end{array}$ & $\begin{array}{l}\text { Arizona, Colorado, } \\
\text { Oregon, Utah }\end{array}$ & Survey & $\begin{array}{l}\text { Fuels management, } \\
\text { Communication }\end{array}$ & $\begin{array}{l}\text { Knowledge, } \\
\text { Information, } \\
\text { Fuels reduction, } \\
\text { Health and safety, } \\
\text { Differences }\end{array}$ \\
\hline Burns and Cheng 2007 & Colorado & Interviews & Active management & $\begin{array}{l}\text { Knowledge, } \\
\text { Fuels reduction, } \\
\text { Differences }\end{array}$ \\
\hline Carroll et al. 2004 & Washington & Interviews & $\begin{array}{l}\text { Fire management, } \\
\text { Tribal views }\end{array}$ & $\begin{array}{l}\text { Knowledge, Smoke, } \\
\text { Differences }\end{array}$ \\
\hline $\begin{array}{l}\text { Cohn et al. 2008, } \\
\text { Carroll et al. } 2005 \text { (AZ only) }\end{array}$ & $\begin{array}{l}\text { Arizona, Colorado, } \\
\text { Idaho, Montana, Utah }\end{array}$ & Interviews & Fire experience & $\begin{array}{l}\text { Knowledge, } \\
\text { Responsibility }\end{array}$ \\
\hline
\end{tabular}




\begin{tabular}{|c|c|c|c|c|}
\hline Study citation & Study site(s) & Method & General topics & Questions \\
\hline $\begin{array}{l}\text { Collins and Bolin 2009, } \\
\text { Collins } 2009\end{array}$ & Arizona & $\begin{array}{l}\text { Survey, } \\
\text { Participant } \\
\text { observation, } \\
\text { Interviews }\end{array}$ & Defensible space & $\begin{array}{l}\text { Knowledge, Cost, } \\
\text { Differences }\end{array}$ \\
\hline Daniel 2006 & Minnesota & Survey & Forest management & Fuels reduction \\
\hline Fischer 2011 & Oregon & Survey & Fuels management & $\begin{array}{l}\text { Fuels reduction, } \\
\text { Responsibility, } \\
\text { Differences }\end{array}$ \\
\hline $\begin{array}{l}\text { Flint } 2006, \\
\text { Flint } 2007\end{array}$ & Alaska & $\begin{array}{l}\text { Interviews, } \\
\text { Survey }\end{array}$ & Beetle kill impacts & $\begin{array}{l}\text { Knowledge, } \\
\text { Health and safety }\end{array}$ \\
\hline Gordon et al. 2010 & West Virginia & Interviews & Fire management & $\begin{array}{l}\text { Knowledge, } \\
\text { Responsibility, }\end{array}$ \\
\hline $\begin{array}{l}\text { Gunderson and Watson 2007, } \\
\text { Gunderson } 2006\end{array}$ & Montana & Interviews & $\begin{array}{l}\text { Fuels treatments, } \\
\text { Place values }\end{array}$ & Fuels reduction \\
\hline Jacobson et al. 2001 & Florida & $\begin{array}{l}\text { Telephone } \\
\text { survey }\end{array}$ & $\begin{array}{l}\text { Fire management, } \\
\text { Defensible space }\end{array}$ & Knowledge, Smoke \\
\hline Jarrett et al. 2009 & $\begin{array}{l}\text { Alabama, Florida, } \\
\text { Georgia, Mississippi, } \\
\text { South Carolina }\end{array}$ & Survey & $\begin{array}{l}\text { Fire management, } \\
\text { Communication }\end{array}$ & $\begin{array}{l}\text { Information, } \\
\text { Differences }\end{array}$ \\
\hline $\begin{array}{l}\text { Kaval et al. 2006, Kaval 2007, } \\
\text { Kaval and Loomis } 2008\end{array}$ & Colorado Front Range & Survey & $\begin{array}{l}\text { Fuels treatments, } \\
\text { Willingness to pay }\end{array}$ & $\begin{array}{l}\text { Fuels reduction, } \\
\text { Cost }\end{array}$ \\
\hline Kent et al. 2003 & Colorado, Hayman Fire & $\begin{array}{l}\text { Interviews, } \\
\text { Focus groups }\end{array}$ & $\begin{array}{l}\text { Fuels treatments, } \\
\text { Defensible space, } \\
\text { Communication }\end{array}$ & $\begin{array}{l}\text { Knowledge, } \\
\text { Information, } \\
\text { Fuels reduction, } \\
\text { Responsibility }\end{array}$ \\
\hline $\begin{array}{l}\text { Kneeshaw et al. } 2004 a \text {, } \\
\text { Kneeshaw et al. } 2004 \text { b }\end{array}$ & $\begin{array}{l}\text { California, Colorado, } \\
\text { Oregon }\end{array}$ & Survey & Fire management & $\begin{array}{l}\text { Fuels reduction, } \\
\text { Smoke, Differences }\end{array}$ \\
\hline Knotek et al. 2008 & Montana & Survey & $\begin{array}{l}\text { Prescribed fire, } \\
\text { Wilderness visitors }\end{array}$ & $\begin{array}{l}\text { Knowledge, } \\
\text { Fuels reduction }\end{array}$ \\
\hline $\begin{array}{l}\text { Liou et al. } 2007 \text {, } \\
\text { Kwon et al. } 2008\end{array}$ & Michigan & Survey (panel) & Fuels management & Differences \\
\hline Kumagai et al. 2004 & California & $\begin{array}{l}\text { Survey, } \\
\text { Interviews }\end{array}$ & Post-fire & Information \\
\hline Loomis et al. 2001 & Florida & Survey & $\begin{array}{l}\text { Prescribed fire, } \\
\text { Educational } \\
\text { materials }\end{array}$ & Knowledge, Smoke \\
\hline Martin et al. 2007 & Colorado and Oregon & Survey & Defensible space & Responsibility, Cost \\
\hline McCaffrey 2006 & Multiple & $\begin{array}{l}\text { Synthesis } \\
\text { of multiple } \\
\text { research } \\
\text { reports }\end{array}$ & Prescribed fire & $\begin{array}{l}\text { Fuels reduction, } \\
\text { Smoke }\end{array}$ \\
\hline
\end{tabular}




\begin{tabular}{|c|c|c|c|c|}
\hline Study citation & Study site(s) & Method & General topics & Questions \\
\hline McCaffrey 2008b & $\begin{array}{l}\text { Arizona, California, } \\
\text { Colorado, Montana, } \\
\text { Nevada }\end{array}$ & Focus groups & $\begin{array}{l}\text { Defensible space, } \\
\text { Risk perception }\end{array}$ & $\begin{array}{l}\text { Knowledge, } \\
\text { Responsibility, } \\
\text { Differences }\end{array}$ \\
\hline $\begin{array}{l}\text { McCaffrey 2008a, } \\
\text { McCaffrey } 2004\end{array}$ & Nevada & Survey & $\begin{array}{l}\text { Fuels treatments, } \\
\text { Defensible space, } \\
\text { Communication }\end{array}$ & $\begin{array}{l}\text { Information, } \\
\text { Fuels reduction, } \\
\text { Smoke, Cost, } \\
\text { Differences }\end{array}$ \\
\hline McCaffrey et al. 2008 & California & $\begin{array}{l}\text { Survey } \\
\text { (Post-treatment } \\
\text { field tour) }\end{array}$ & Fuels treatments & $\begin{array}{l}\text { Information, } \\
\text { Fuels reduction, } \\
\text { Cost, Differences }\end{array}$ \\
\hline McCaffrey and Winter 2011 & $\begin{array}{l}\text { California, Florida, } \\
\text { Montana }\end{array}$ & Survey & $\begin{array}{l}\text { Defensible space, } \\
\text { Evacuation }\end{array}$ & Responsibility \\
\hline McFarlane et al. 2007 & Canada & Interviews & $\begin{array}{l}\text { Fire management, } \\
\text { Defensible space, } \\
\text { Communication }\end{array}$ & $\begin{array}{l}\text { Knowledge, } \\
\text { Fuels reduction, } \\
\text { Smoke, } \\
\text { Health and safety }\end{array}$ \\
\hline McGee 2011 & $\begin{array}{l}\text { Canada, Australia, } \\
\text { United States }\end{array}$ & Interviews & Defensible space & $\begin{array}{l}\text { Information, } \\
\text { Fuels reduction, } \\
\text { Responsibility }\end{array}$ \\
\hline Mendez et al. 2003 & Washington & Interviews & Fire management & $\begin{array}{l}\text { Knowledge, } \\
\text { Differences }\end{array}$ \\
\hline $\begin{array}{l}\text { Monroe and Nelson } 2004 \text {, } \\
\text { Monroe et al. 2006, } \\
\text { Nelson et al. } 2004\end{array}$ & Florida, Minnesota & $\begin{array}{l}\text { Interviews, } \\
\text { Survey }\end{array}$ & $\begin{array}{l}\text { Fuels management, } \\
\text { Defensible space }\end{array}$ & $\begin{array}{l}\text { Knowledge, } \\
\text { Information, } \\
\text { Fuels reduction, } \\
\text { Responsibility, } \\
\text { Differences }\end{array}$ \\
\hline Olsen and Shindler 2010 & Oregon & Survey & $\begin{array}{l}\text { Post-fire } \\
\text { management } \\
\text { practices }\end{array}$ & Fuels reduction \\
\hline Ostergren et al. 2006 & Arizona & Survey & Communication & Information \\
\hline $\begin{array}{l}\text { Paveglio et al. } 2009 \text {, } \\
\text { Paveglio et al. } 2011\end{array}$ & Washington & Focus groups & $\begin{array}{l}\text { Fire management, } \\
\text { Communication }\end{array}$ & $\begin{array}{l}\text { Knowledge, } \\
\text { Information, } \\
\text { Fuels reduction, } \\
\text { Responsibility }\end{array}$ \\
\hline Parkinson et al. 2003 & Idaho & $\begin{array}{l}\text { Educational } \\
\text { workshops }\end{array}$ & $\begin{array}{l}\text { Education } \\
\text { effectiveness }\end{array}$ & Knowledge \\
\hline Rasmussen et al. 2007 & Oregon, Washington & Interviews & $\begin{array}{l}\text { Fire management, } \\
\text { Tribal views }\end{array}$ & Cost \\
\hline $\begin{array}{l}\text { Ryan et al. 2006, Ryan } 2010, \\
\text { Blanchard and Ryan } 2007 \text { (MA } \\
\text { only), Ryan and Wamsley } 2008 \\
\text { (NY only) }\end{array}$ & $\begin{array}{l}\text { Long Island, New York, } \\
\text { Massachusetts }\end{array}$ & Survey & $\begin{array}{l}\text { Fire management, } \\
\text { Defensible space }\end{array}$ & $\begin{array}{l}\text { Knowledge, } \\
\text { Fuels reduction, } \\
\text { Smoke, Responsibility, } \\
\text { Differences }\end{array}$ \\
\hline
\end{tabular}




\begin{tabular}{|c|c|c|c|c|}
\hline Study citation & Study site(s) & Method & General topics & Questions \\
\hline Ryan and Hamin 2008 & $\begin{array}{l}\text { California, Colorado, } \\
\text { New Mexico }\end{array}$ & $\begin{array}{l}\text { Interviews, } \\
\text { Focus groups }\end{array}$ & Post-fire recovery & Information \\
\hline Shiralipour et al. 2006 & $\begin{array}{l}\text { Alaska, Colorado, } \\
\text { Florida, New Jersey, } \\
\text { South Dakota, Texas }\end{array}$ & Interviews & $\begin{array}{l}\text { Defensible space, } \\
\text { Neighborhood } \\
\text { organizations }\end{array}$ & Responsibility \\
\hline Shindler and Toman 2003 & Oregon, Washington & $\begin{array}{l}\text { Survey } \\
\text { (longitudinal) }\end{array}$ & Fuels treatments & $\begin{array}{l}\text { Information, } \\
\text { Fuels reduction, } \\
\text { Smoke, Differences }\end{array}$ \\
\hline Shindler et al. 2009 & $\begin{array}{l}\text { Michigan, Minnesota, } \\
\text { Wisconsin }\end{array}$ & Survey & $\begin{array}{l}\text { Fire management, } \\
\text { Communication }\end{array}$ & $\begin{array}{l}\text { Information, } \\
\text { Fuels reduction, } \\
\text { Differences }\end{array}$ \\
\hline Shindler et al. 2011 & $\begin{array}{l}\text { Idaho, Nevada, } \\
\text { Oregon, Utah }\end{array}$ & $\begin{array}{l}\text { Survey, } \\
\text { Interviews }\end{array}$ & Fuels management & $\begin{array}{l}\text { Information, } \\
\text { Fuels reduction, } \\
\text { Differences }\end{array}$ \\
\hline Schulte and Miller 2010 & $\begin{array}{l}\text { Colorado } \\
\text { (Front Range) }\end{array}$ & Survey & $\begin{array}{l}\text { Defensible space, } \\
\text { Climate change }\end{array}$ & Responsibility \\
\hline Steelman and McCaffrey 2010 & $\begin{array}{l}\text { Arizona, California, } \\
\text { Colorado, New Mexico }\end{array}$ & Survey & $\begin{array}{l}\text { During-fire } \\
\text { communication }\end{array}$ & $\begin{array}{l}\text { Health and safety, } \\
\text { Cost }\end{array}$ \\
\hline Taylor et al. 2007 & California & $\begin{array}{l}\text { Participant } \\
\text { observation, } \\
\text { Interviews, } \\
\text { Focus groups }\end{array}$ & $\begin{array}{l}\text { During-fire } \\
\text { communication }\end{array}$ & Information \\
\hline Thapa et al. 2004 & Florida & Survey & $\begin{array}{l}\text { Effect of fire on } \\
\text { visitor plans }\end{array}$ & Smoke, Responsibility \\
\hline Toman et al. 2004 & Oregon & $\begin{array}{l}\text { Survey } \\
\text { (Pre and post } \\
\text { site visit) }\end{array}$ & $\begin{array}{l}\text { Effect of field tour on } \\
\text { prescribed burning } \\
\text { attitudes }\end{array}$ & Fuels reduction \\
\hline Toman et al. 2008 & Oregon & Survey & $\begin{array}{l}\text { Post-treatment field } \\
\text { tour assessment }\end{array}$ & $\begin{array}{l}\text { Information, } \\
\text { Fuels reduction }\end{array}$ \\
\hline Toman and Shindler 2006 & California, Oregon & $\begin{array}{l}\text { Survey (pre- } \\
\text { and post- } \\
\text { treatment visit) }\end{array}$ & $\begin{array}{l}\text { Fire management, } \\
\text { communication }\end{array}$ & $\begin{array}{l}\text { Knowledge, } \\
\text { Fuels reduction, } \\
\text { Smoke }\end{array}$ \\
\hline $\begin{array}{l}\text { Toman et al. } 2011 \text { (OR and UT } \\
\text { only), McCaffrey et al. } 2011\end{array}$ & Oregon, Utah, Idaho & $\begin{array}{l}\text { Interviews, } \\
\text { Survey }\end{array}$ & $\begin{array}{l}\text { Defensible space, } \\
\text { Fuels treatments, } \\
\text { Communication }\end{array}$ & $\begin{array}{l}\text { Information, } \\
\text { Fuels reduction, } \\
\text { Responsibility, } \\
\text { Differences }\end{array}$ \\
\hline Vining and Merrick 2008 & Florida, Minnesota & $\begin{array}{l}\text { Decision } \\
\text { analysis survey }\end{array}$ & Fuels management & $\begin{array}{l}\text { Knowledge, } \\
\text { Fuels reduction, } \\
\text { Responsibility, } \\
\text { Health and safety, Cost }\end{array}$ \\
\hline Vogt et al. 2007 & Missouri & Survey & Fuels treatments & $\begin{array}{l}\text { Information, } \\
\text { Fuels reduction, } \\
\text { Differences }\end{array}$ \\
\hline
\end{tabular}




\begin{tabular}{|c|c|c|c|c|}
\hline Study citation & Study site(s) & Method & General topics & Questions \\
\hline $\begin{array}{l}\text { Vogt et al. 2009, } \\
\text { Winter et al. } 2009\end{array}$ & $\begin{array}{l}\text { California, Colorado, } \\
\text { Michigan, New Mexico }\end{array}$ & $\begin{array}{l}\text { Focus groups, } \\
\text { Survey }\end{array}$ & Defensible space & $\begin{array}{l}\text { Information, } \\
\text { Responsibility, } \\
\text { Health and safety, } \\
\text { Cost, }\end{array}$ \\
\hline Walker et al. 2007 & $\begin{array}{l}\text { Colorado } \\
\text { (Front Range) }\end{array}$ & Survey & $\begin{array}{l}\text { Fuels treatments } \\
\text { (Willingness to pay) }\end{array}$ & Fuels reduction \\
\hline Weible et al. 2005 & California & Survey & Thinning & Differences \\
\hline Weisshaupt et al. 2007 & Washington, Montana & Focus groups & Fire management & $\begin{array}{l}\text { Knowledge, } \\
\text { Smoke, Responsibility, } \\
\text { Cost, Differences }\end{array}$ \\
\hline $\begin{array}{l}\text { Winter et al. } 2002 \text {, } \\
\text { Winter et al. } 2004, \\
\text { Winter et al. } 2006 \text { (+ MO), } \\
\text { Vogt et al. } 2005 \text {, Vogt } 2003 \text {, } \\
\text { Fried et al. } 2006\end{array}$ & $\begin{array}{l}\text { California, Florida, } \\
\text { Michigan }\end{array}$ & Survey & $\begin{array}{l}\text { Defensible space, } \\
\text { Fuels treatments }\end{array}$ & $\begin{array}{l}\text { Fuels reduction, } \\
\text { Smoke, Cost, } \\
\text { Differences }\end{array}$ \\
\hline Winter and Cvetkovich 2008 & $\begin{array}{l}\text { Arizona, California, } \\
\text { Colorado, New Mexico }\end{array}$ & Survey & Fire management & $\begin{array}{l}\text { Knowledge, } \\
\text { Differences }\end{array}$ \\
\hline Winter and Cvetkovich 2010 & California & $\begin{array}{l}\text { Focus groups, } \\
\text { Survey }\end{array}$ & $\begin{array}{l}\text { Defensible space, } \\
\text { Fire management }\end{array}$ & $\begin{array}{l}\text { Information, } \\
\text { Fuels reduction, } \\
\text { Responsibility }\end{array}$ \\
\hline
\end{tabular}


McCaffrey, Sarah M.; Olsen, Christine S. 2012. Research perspectives on the public and fire management: a synthesis of current social science on eight essential questions. Gen. Tech. Rep. NRS-104. Newtown Square, PA: U.S. Department of Agriculture, Forest Service, Northern Research Station. 40 p.

As part of a Joint Fire Science Program project, a team of social scientists reviewed existing fire social science literature to develop a targeted synthesis of scientific knowledge on the following questions: 1 . What is the public's understanding of fire's role in the ecosystem? 2. Who are trusted sources of information about fire? 3. What are the public's views of fuels reduction methods, and how do those views vary depending on citizens' location in the wildland-urban interface or elsewhere? 4. What is the public's understanding of smoke effects on human health, and what shapes the public's tolerance for smoke? 5. What are homeowners' views of their responsibilities for home and property protection and mitigation, e.g., defensible space measures? 6 . What role does human health and safety play in the public's perceptions of fire and fire management? 7 . What are the public's views on the role and importance of costs in wildfire incident response decisions? 8 . To the extent that information is available, how do findings differ among ethnic and cultural groups, and across regions of the country?

Despite limited fire research specific to the questions on costs, and human health and safety, common findings on all these interrelated topics are summarized in this document. Research has found that the public has a fairly sophisticated understanding of fire's ecological role and the environmental factors that can increase fire risk. The public obtains information on fire from a wide variety of sources, but findings consistently show that interactive information sources are both generally preferred and more effective than unidirectional sources. As a way to improve ecosystem health and reduce fire risk, active land management generally has greater citizen support than a no-action alternative. Most respondents accept the practice of prescribed fire for active forest management and tolerate the accompanying smoke; in contrast, smoke is a highly salient issue for households with health concerns. The public tends to see mitigating the fire risk as a shared responsibility with landowners, whether public or private, responsible for taking appropriate action on their own property. Cost figures in to citizens' decisionmaking about actions to protect property before a wildfire but may be less of a priority during incident response. Except for ethnicity or race, little evidence was found of meaningful variation in public response to fire management based on sociodemographic characteristics or geographic variation.

KEY WORDS: public acceptance, information sources, fuels treatments, mitigation, smoke, wildland-urban interface, responsibility, risk, geographic variation

The U.S. Department of Agriculture (USDA) prohibits discrimination in all its programs and activities on the basis of race, color, national origin, age, disability, and where applicable, sex, marital status, familial status, parental status, religion, sexual orientation, genetic information, political beliefs, reprisal, or because all or part of an individual's income is derived from any public assistance program. (Not all prohibited bases apply to all programs.) Persons with disabilities who require alternate means for communication of program information (Braille, large print, audiotape, etc.) should contact USDA's TARGET Center at (202) 720-2600 (voice and TDD). To file a complaint of discrimination, write to USDA, Director, Office of Civil Rights, 1400 Independence Avenue, S.W., Washington, DC 20250-9410, or call (800) 795-3272 (voice) or (202) 720-6382 (TDD). USDA is an equal opportunity provider and employer. 


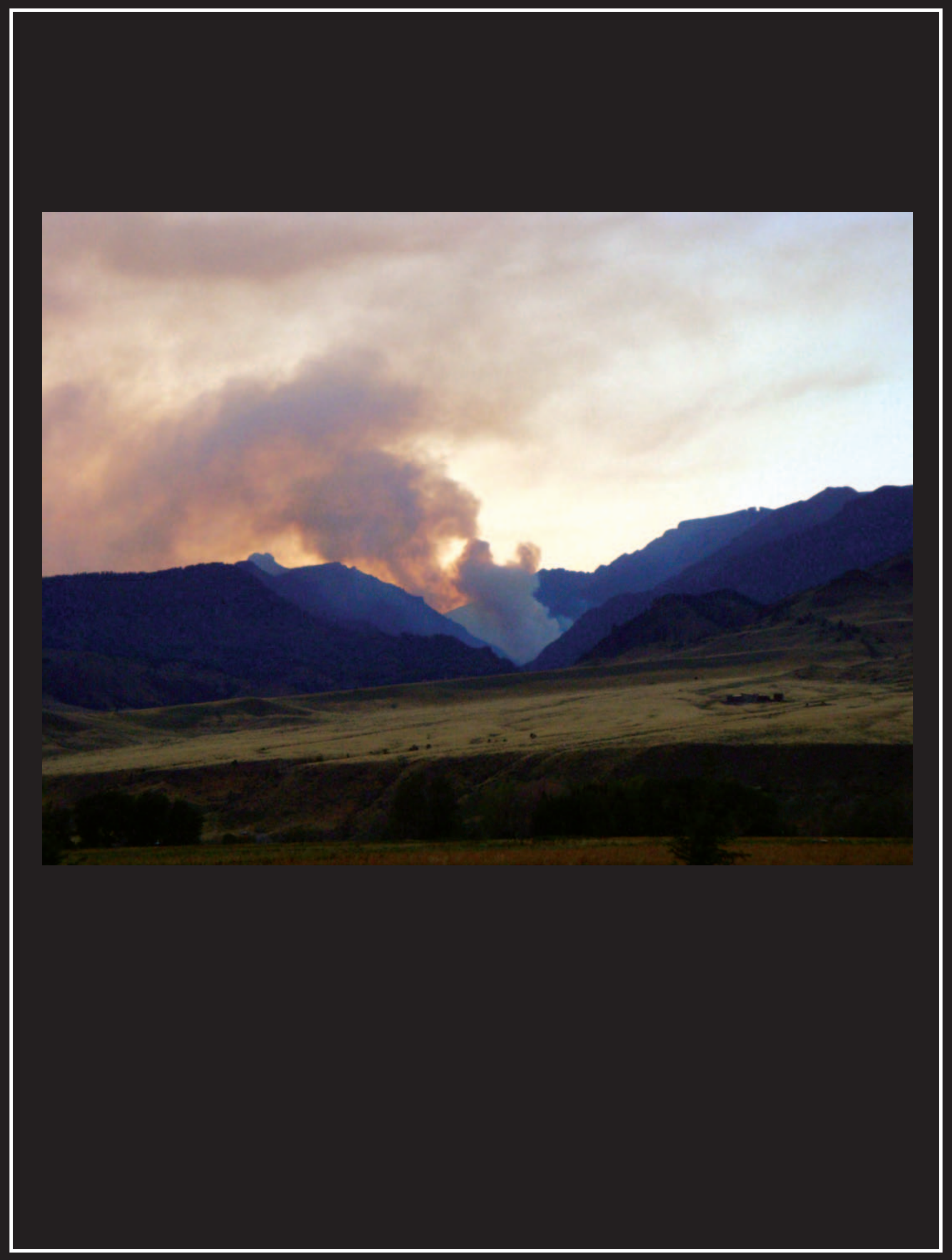

